\title{
Role of Leptomycin in p53 Induced Apoptosis
}

Siva Chandran Ramakrishna*

Sheffield Hallam University, City Campus, United Kingdom

\begin{abstract}
Purpose: Leptomycin B [LMB] is an anti fungal metabolite which was tested for anti cancer activity, but failed in clinical trials due to non specific killing at higher concentrations. Leptomycin B acts on CRM1, a nuclear export protein that exports p53 out of the nucleus. Leptomycin B blocks CRM1, hence leading to sequestration of p53 in the nucleus, which in turn leads to apoptosis. DR5 antibody is one of the most successful compounds being used in the market for cancer therapy. In this project, Leptomycin B is combined with DR5 [dual treatment] and tested on PC3, LNCAP and MCF7 cells to find out whether leptomycin B increases the percentage of apoptotic cells. This project aims at testing leptomycin B on PC 3 cells which are p53 null mutants, and to find out the expression levels of p53 related genes using RT-PCR. Nutlin 3a, a MDM2 antagonist is also combined with dual treatment to check whether there is increased apoptosis.
\end{abstract}

Results: Leptomycin induced apoptosis in PC3 cells [p53 null mutants] even at lower concentrations. Dual treatment showed an increased percentage in apoptotic cells when compared to DR5 alone treatment. Nutlin was also found to induce apoptosis in PC3 cells.

Conclusion: Leptomycin B and Nutlin 3a induce p53 independent apoptosis. Dual treatment can be considered for further trials for better killing of cancer cells.

\section{Introduction}

Cancer is a phenomenon in which cells display uncontrolled proliferation and invade and destroy the adjacent tissues or enter the blood stream/lymph to spread to other locations of the body [metastasis]. Sometimes, they do not metastasize and form benign tumours [1]. Cancer is due to failure of regulation of tissue growth. Due to an alteration in the genes which regulate cell growth and differentiation, a normal cell converts into a cancer cell. The genes that are affected are classified into two categories. Cell growth and reproduction regulated by oncogenes. Cell division and survival is inhibited by tumour suppressor genes. Due to the formation of novel oncogenes or inappropriate over-expression of normal oncogenes, or due to the under-expression or null expression of tumour suppressor genes, malignant transformation can occur [2]. These genetic changes occur at different levels and by different mechanisms. These could be either a gain or loss of an entire chromosome or a part of it. But, generally, mutations have been found to be the major factors for these genetic changes [3].

\section{Hallmarks of cancer}

In cancer cells, there are defects in the regulatory cicuits that govern normal cell proliferation and homeostasis. More than 100 distinct types of cancer exist and there are tumour subtypes within specific organs. The different cancer cell genotypes are exhibited due to the following six important alterations that cause malignant growth as described in Figure 1:

(1) Abundancy in growth signals

(2) Unresponsive to growth inhibitory signals

(3) High replication potential

(4) Sustained angiogenesis

(5) Tissue invasion

(6) Metastasis
This explains the invasion into the defense system of anti cancer machinery [4].

Unresponsivenes to anti growth signals: To mainain tissue homeostasis and quiscence, there are many anti proliferative signals within a normal tissue. Proliferation can be blocked by anti proliferative signals through two mechanisms:

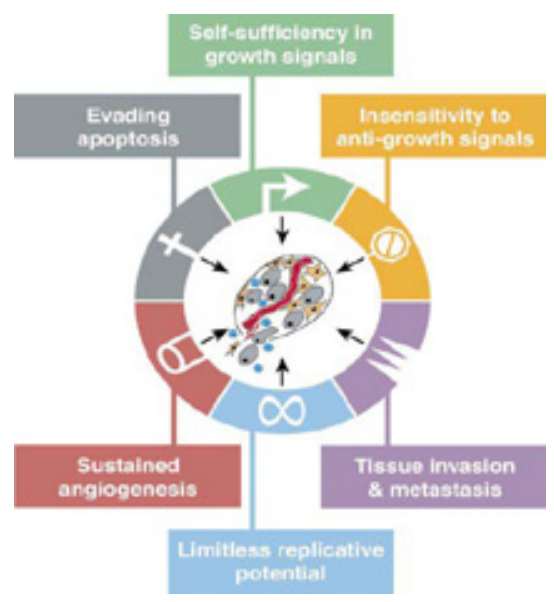

Figure 1: Acquired capabilities of cancer [4]

*Corresponding author: Siva Chandran Ramakrishna, Biosciences, Sheffield Hallam University, Howard street, City Campus, Sheffield, South Yorshire S1 1WB, United Kingdom, Tel: +91-40-27955697; E-mail: sivachandranramakrishna@ gmail.com

Received March 06, 2013; Accepted April 12, 2013; Published April 14, 2013

Citation: Ramakrishna SC (2013) Role of Leptomycin in p53 Induced Apoptosis. J Cancer Sci Ther 5: 158-181. doi:10.4172/1948-5956.1000203

Copyright: (c) Ramakrishna SC. This is an open-access article distributed under the terms of the Creative Commons Attribution License, which permits unrestricted use, distribution, and reproduction in any medium, provided the original author and source are credited. 
(1) Cells are directed towards $\mathrm{G}_{0}$ (quiscent) state from an actively proliferative state. These cells exit $\mathrm{G}_{0}$ state when the extracellular signals are provided.

(2) Instead of proliferation, cells are forced to differentiate into specific tissues.

Cancer cells are supposed to evade these signals if they are to surivive and prosper [5].

Abundancy in growth signals: The growth signal pathway has many cross connections that allow extracellular signals to invoke multiple effects on the cell. The mechanisms of growth signalling are complex due to alteration in the downstream signals that are activated by the ligand-receptor (integrin) interactions. Cancer cells are capable of switching the receptors (integrins) on their surface to the types that promote their growth. The binding of such signals for the extracellular matrix enables the integrin receptors to transmit signals into the cytoplasm that cause a change in behaviour of the cell, for example, a shift from quiescence to motility, apoptosis from resistance, active cell division from quiescence etc [6].

In a normal tissue, cells usually grow with the help of their neighbours through paracrine signalling or through systemic (endocrine) signalling. A similar cell to cell signalling is likely to be seen in majority of tumours, which consist of different cell types that communicate through heterotypic signalling. Between these various cell types, heterotypic signalling likely plays an important role in the proliferation of tumour cells as described in Figure 2. These growth signals seem to be derived from components of the stromal cell in the tumour mass. Tumour cells have the capacity to co-opt with their neighbouring cells by eliciting a response to release adequate growth signals [7].

Evading apoptosis: The hallmark of most cancers/carcinogenesis is the resistance towards apoptosis. In the body, apoptosis is present in a latent state. It is triggered by various physiologic signals, after which a cascade of events occur in a programmed manner. These events involve disruption of cell membrane, breaking down of nuclear and cytoplasmic components, extrusion of cytoplasm, the degradation of chromosomes and the fragmentation of nucleus. Cancer cells harbour alterations to evade apoptosis [4].

Unlimited replicatie potential: In case of mammalian cells, there is an intrinsic system that controls the multiplication of the cell, and it functions independent of cell to cell signalling. Cells reach a stage of senescence after certain rounds of replication. This is regulated by the tumour suppresor proteins $\mathrm{pRb}$ and $\mathrm{p} 53$. Defects in the genes encoding these proteins leads to immortalization of the cells [8]. In malignant cells, the maintainance of telomeres is clearly eident. In these cells, there is an upregulation of the enzyme telomerase, which maintains the length of the telomeres aboe a particular threshold, which inturn allows unlimited replicatie potential [9].

Sustained angiogenesis: Tumour cells activate angigenesis by altering the response towards angiogenic inducers and inhibitors. The principle behind this is the alteration in gene expression [10]. An increase in expression of VEGFs/FGFs and downregulation of $\beta$-interferons and thrombospondin-1 has been observed in case of tumour cells. Thrombospondin expression has been observed to be linked with p53 levels. p53 upregulates the expression of thrombospondin which regulates angiogenesis. Due to loss of p53 function in most tumour cells, thrombospondin levels are inturn downregulated [11]. Proteases also control the balance of angiogenic inducers and inhibitors [12].

Metastasis and tissue invasion: This is the main reason for the deaths caused by cancer, where the cancerous cells invade the adjacent tissues and start forming new colonies. Many proteins are involved in the tethering of these cells to adjacent tissues, which maily include the proteins involved in cell-cell adhesion. E-cadherin is one of the major proteins that loses its functioning in cancer cells., as it acts as a tumour suppressor and suppressor of metastasis and invasion [13].

Alternate pathways: Mutations in genes like ras and p53 are not found in all subtypes of cancers. In some cases, alterations in tumour suppressor genes and oncogenes occur either early or late in tumourigenesis. During tumour progression, properties such as limitless replicatiion, sustained angiogenesis and apoptosis resistance can occur different stages/time. Although these hallmarks are common in different types of cancer, the timing of these events vary in different cases, till biological endpoint is reached. This is clearly explained in Figure 3 as follows:

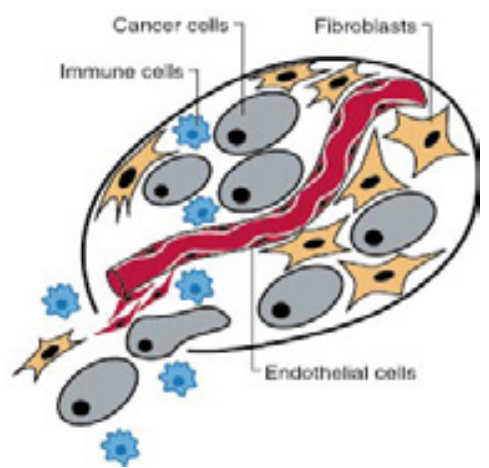

Figure 2: Tumours as complex tissues [4]. Heterotypic signalling is observed between cancer cells and immune cells [paracrine signalling] which helps in proliferation of cancer cells.

A

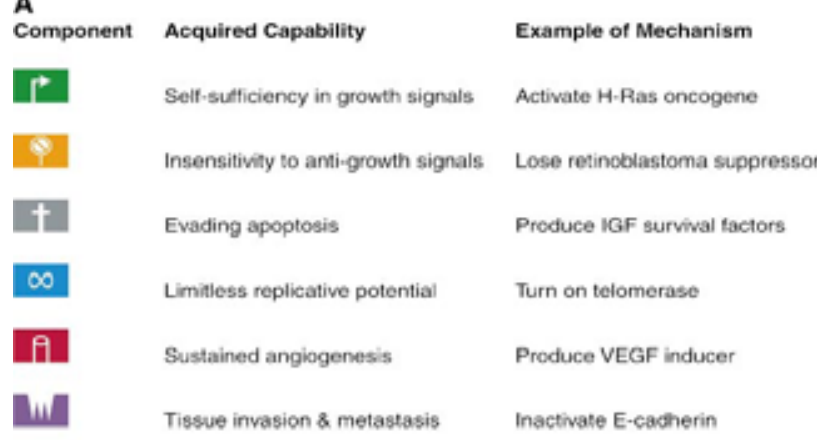

B

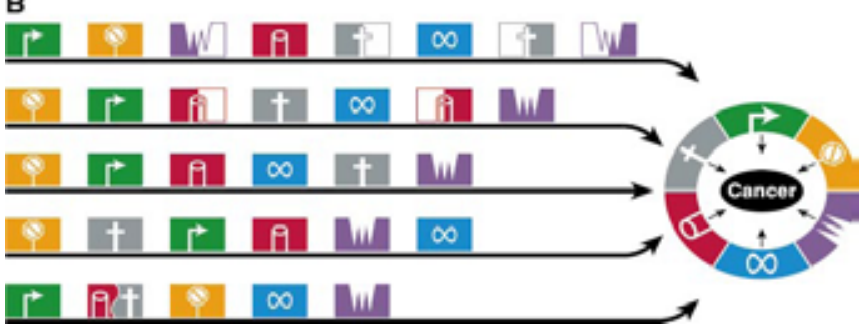
Figure 3: Alternate pathways in tumorigenesis [4]. A series of events are observed in a cancer cell which include abundancy in growth signals, Unresponsive to growth inhibitory signals, High replication potential, Sustained angiogenesis, Tissue invasion and Metastasis. 


\section{Apoptotic signalling}

The process of programmed cell death is termed apoptosis. With the help of apoptosis, damaged and unnecessary cells that result due to DNA damage are removed in a systematic/ orderly manner. Various factors contribute to activation of apoptosis [14]. Programmed cell death can range from necrosis to classical apoptosis as described in Figure 4.

The apoptotic pathways can be described as extrinsic, intrinsic, mitochondrial, death receptor (DR), p53 dependent and p53 independent with respect to initiation \& execution phases [15]. These pathways are highly regulated and interconnected as shown in Figure 4.

Caspases: Caspases are cysteine-aspartate proteases that are involved in apoptotic pathways. Signals activate initiator caspases that in turn activate executioner caspases. The point at which the cell commits to die is called the 'apoptotic commitment point', which involves the activation of executioner caspases. Caspases 3, 6 and 7 are executioner caspases whereas 8,9 and 10 are initiator caspases. These generally exist as pro caspases and are converted to active form on cleavage at the aspartate residues [16]. When apoptosis is induced, extrinsic or intrinsic pathway involves initiator caspases activation. Extrinsic pathways activate initiator caspases 8 and 10, whereas caspase 9 is activated through intrinsic pathway. Executioner caspases are common for both intrinsic and extrinsic pathways [17].

Bcl-2 family: These are intracellular proteins that act as important mediators of apoptosis. There are 2 classes of Bcl-2 proteins based on their function: pro apoptotic and anti apoptotic. The anti apoptotic class of proteins act by inhibiting action of pro apoptotic proteins. Bax protein is an apoptotic protein whose action is inhibited by Bcl-2. When apoptosis is induced through intrinsic pathway, Bax translocates to mitochondrial membrane to release cytochrome $\mathrm{c}$ from mitochondria for the activation of caspase 9 [18].

Intrinsic pathway: In this pathway, the signal for apoptosis is usually generated within the cell due to disruption in homeostasis of the cell. The pathway initiates from the mitochondria, the reason being the localization of many pro apoptotic proteins in the mitochondria. When apoptosis is induced, these proteins are released from the mitochondria [19]. The intrinsic pathway has been described in detail in Figure 5.

When Cytochrome $c$ is released from the mitochondria on induction of apoptosis, it interacts with Apaf- 1 and caspase- 9 to form an apoptosome. This leads to the activation of caspase that was present in the inactive state as procaspase- 9 bound to Apaf-1. Caspase 9 in turn activates caspases 3 and 7 which results in death of the cell [20].

Extrinsic pathway [Death receptor (DR) signalling]: The death receptors on cell surface belong to TNF receptor superfamily. These receptors transmit apoptotic signals by the binding of death ligands. The different classes of ligands include Fas-L, TRAIL, Apo3L and TNF [21].

(1) Fas-L signalling: Fas is expressed in various tissues and it is bound by Fas-L. The binding leads to induction of apoptosis in the target cell. On binding of Fas-L, FADD [Fas associated death domain] protein is recruited which binds to the death domain of Fas receptor intracellularly. The N-terminus of FADD is called DED [death effector domain] which is bound to pro caspases 8 and 10 .

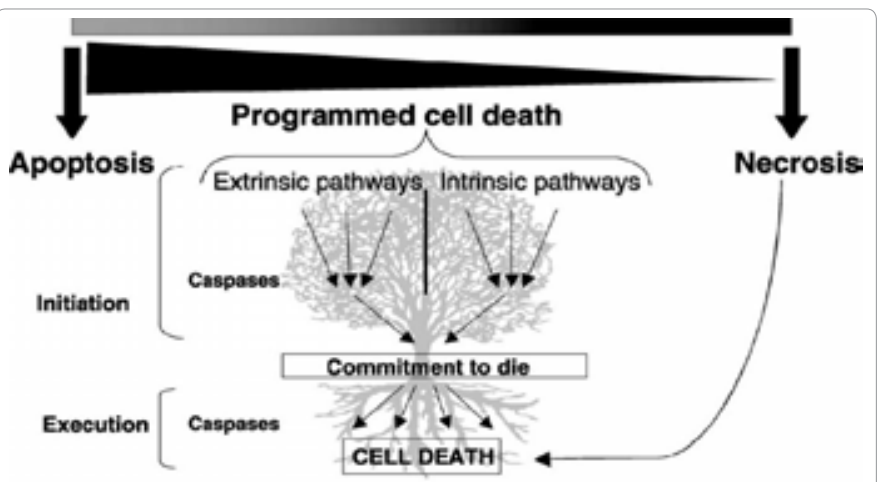

Figure 4: Representation of the continuum of programmed cell death cascades [15]. Programmed cell death can range from necrosis to classical apoptosis. The apoptotic pathways can be described as extrinsic, intrinsic, mitochondrial, death receptor (DR), p53 dependent and p53 independent with respect to initiation \& execution phases.

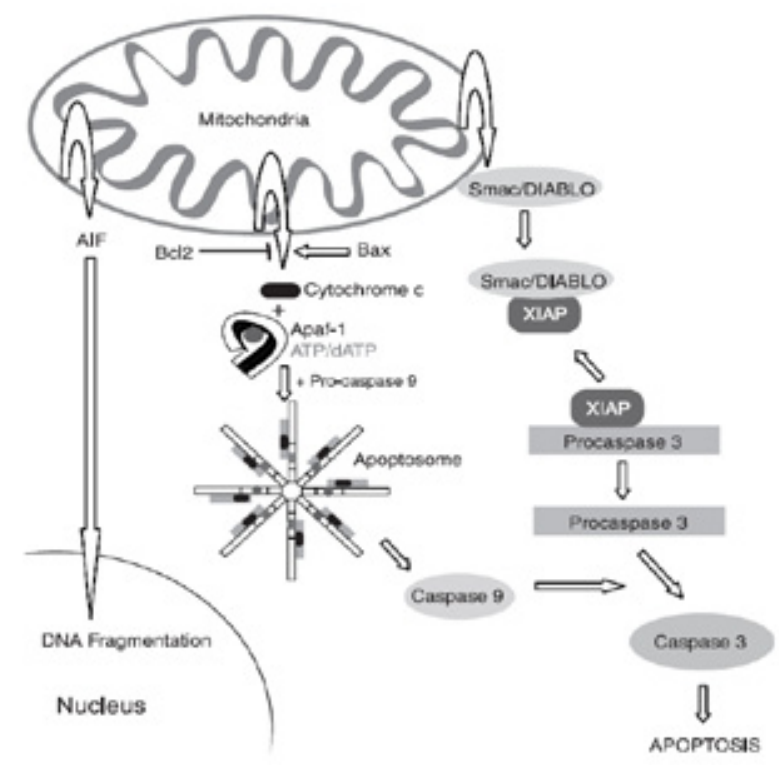

Figure 5: Intrinsic pathway of apoptosis signalling [20]. The intrinsic pathway involves the release of Bax which translocates to mitochondria, releases cytochrome $c$ that activates initiator caspase 9 that causes apoptosis.

Activation of FADD leads to conversion of pro caspases 8 and 10 into active forms, which in turn activate executioner caspases. The complex involving association of Fas-L, Fas, FADD and initiator caspases is termed DISC [Death induced silencing complex] [21]. In some cases, the activation of caspase 8 through FADD involves the cleavage of Bid protein to tBid, which in turn allows the release of cytochrome $c$ from mitochondria [22]. In addition, tBid has been found to be involved in the release of Smac/DIABLO which blocks the anti-apoptotic effect of $\mathrm{Bcl}_{\mathrm{XL}}$ [23]. This process has been described in Figure 6 in detail. FLIP [FLICE Inhibitory Protein] is present in 2 forms: FLIP $_{S}$ and FLIP ${ }_{\mathrm{L}}$. These inhibitory proteins bind to the DED of FADD and inactivate it, preventing apoptosis induction. They also interact with pro caspase 8 of through DED and prevent signal transduction for apoptosis. Due to this binding, pro caspase 8 is not converted to active form and apoptosis is inhibited [24].

(2) TNF signalling: This also involves a major death receptor 
pathway. The signal is transducerd through two receptors- TNF-R1 and TNF-R2. TNF-R1 is responsible for cytotoxicity. When TNF interacts with TNF-R1, an adaptor protein called TRADD [TNF receptor associated death domain] is recruited. TRADD can also interact with FADD and induce apoptosis in the cell [25]. Alternatively, apoptosis can be induced by interaction of death domain of TRADD with RIP, which in turn is bound by RAIDD [RIP adaptor with death domain]. RAIDD in turn activates caspase 2. Like caspase 8 , caspase 2 cleaves Bid to tBid and allows release of cytochrome $c$, AIF and Smac/Diablo [26]. This process has been described in detail in Figure 7. Alternatively, recruitment of TRAF 2 by TRADD can lead to activation of JAK and NF-kB. In contrast to role of JNK in apoptosis, it has been observed that NF-kB activation protects cells from TNF induced apoptosis [27].

(3) TRAIL signalling: TRAIL [Tumour necrosis factor $\alpha$-related apoptosis-inducing ligand] is a death ligand expressed in most human tissues. DcR1, DcR2, DR4 and DR5 are the death receptors to which TRAIL binds specifically. DcR's [decoy receptors] inhibit apoptosis by binding to the death ligands. These decoy receptors do not possess a transmembrane domain [28]. Trail is also called Apo2L due to homology with the TNF family and Fas/Apo1 ligand. In humans, it consists of 281 amino acids and is expressed as a type II transmembrane protein. It is mostly expressed in immune cells and plays a key role in killing of oncogenic cells by T-cells [29]. TRAIL binds to two kinds of apoptosis inducing receptors: DR4 [TRAIL-R1] and DR5 [TRAIL-R2]. Binding to DcR1 [TRAIL-R3] and DcR2 [TRAIL-R4] does not transmit

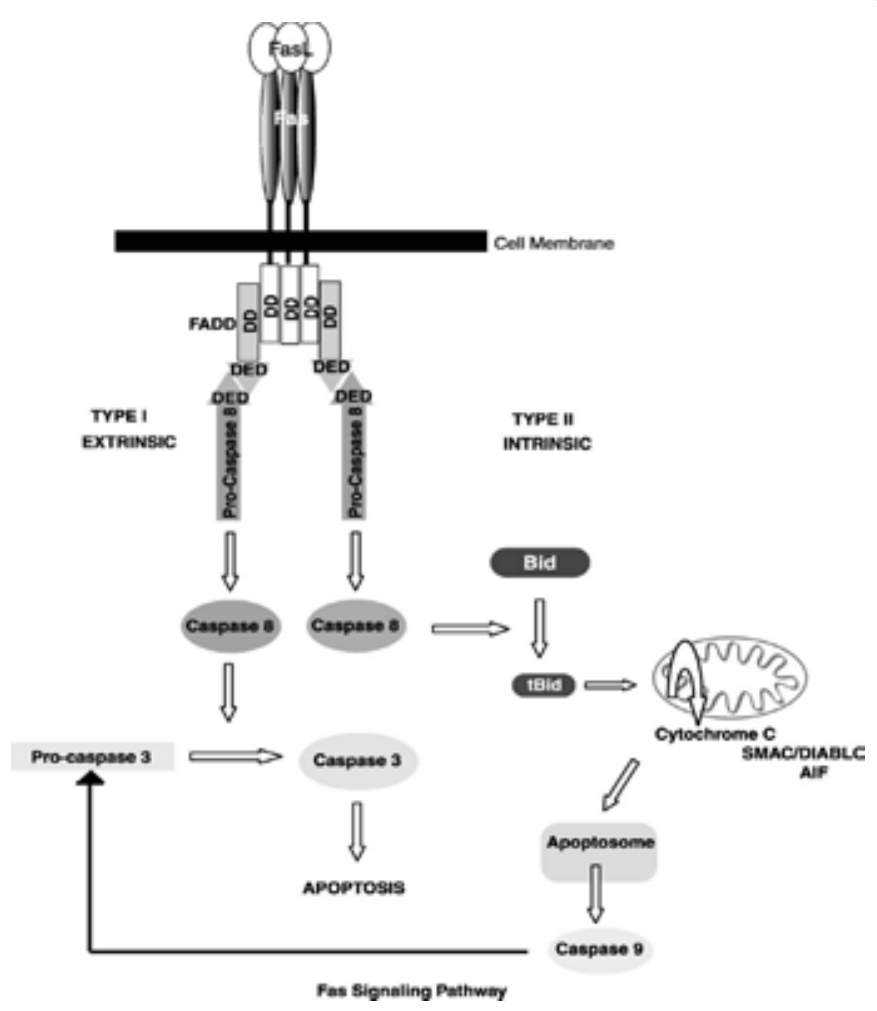

Figure 6: Representation of Fas-mediated apoptosis signalling [15]. Activation of caspase 8 through binding of Fas $L$ to Fas receptor directly activates downstream caspases including caspases 3,6 , and 7 . The mitochondrial amplification loop has been demonstrated to involve the caspase 8-mediated cleavage of Bid to tBid which results in the release of Smac/DIABLO from mitochondria.

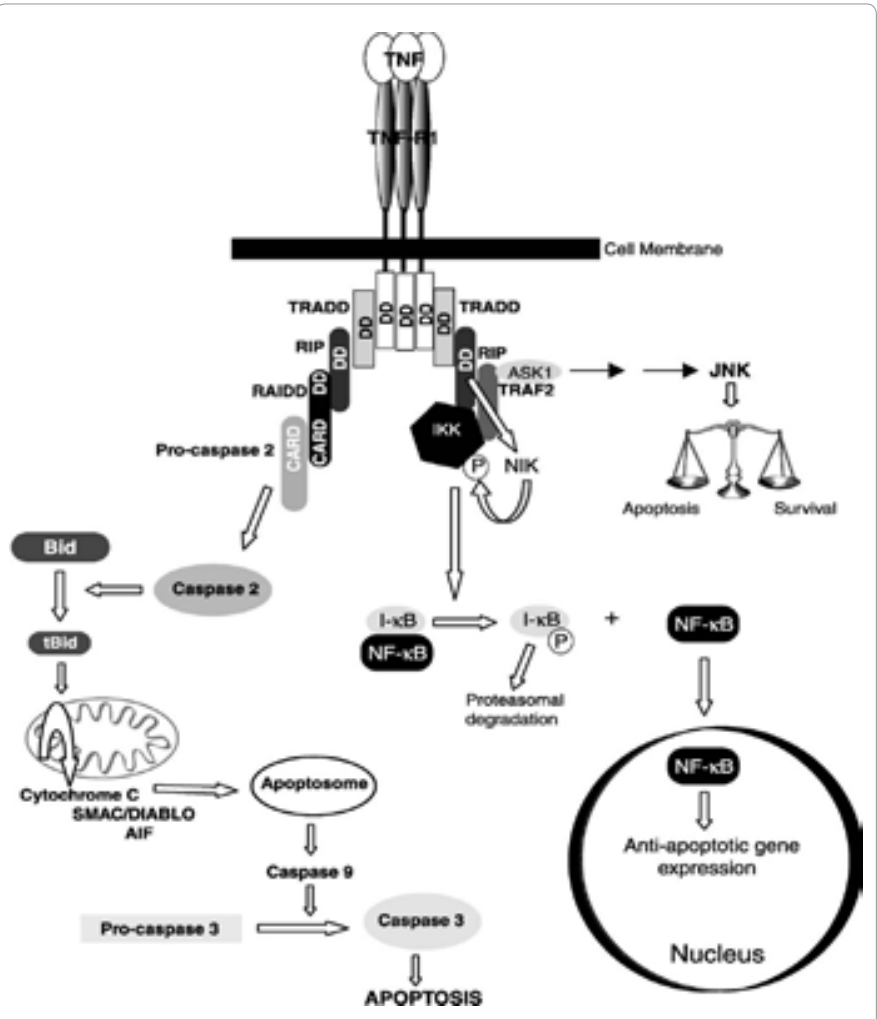

Figure 7: Representation of TNF-R1-mediated apoptosis signalling [15]. The interaction of TNF with TNF receptor promotes the recruitment of TRADD TRADD can interact with FADD and activate caspases 8/10. TRADD can also activate NF-kB which is anti-apoptotic. Release of Smac/DIABLO through tBid activation by caspase 8 inhibits XIAP and activates caspase 3 .

the apoptotic signal. TRAIL also binds to soluble decoy receptor called OPG [osteoprotegerin] [30].

Binding of TRAIL to DR4 or DR5 results in the formation of DISC [Death induced silencing complex]. Then, FADD is recruited, whose death domain binds to DISC, which in turn recruits pro caspases 8 and 10. These pro caspases are then activated which transmit the apoptotic signal by activating executioner caspases [31]. The activation of caspase 8 and 10 can be inhibited by c-FLIP, which is a FLICE like inhibitory protein. c-FLIP is recruited at the DISC by death effector domain interactions and blocks the processing of caspases 8 and 10 at the DISC by interacting with FADD [32]. Once caspase 8 is activated, it acts on two specific targets- Bid and caspase 3 . Activation of caspase 3 leads to apoptosis. Cleavage of Bid leads to formation of $\mathrm{tBid}$ which translocates to mitochondria and activates Bak and Bax. This in turn leads to the release of pro apoptotic factors and cytochrome $\mathrm{c}$ from mitochondria [33]. Activation of caspase 3 is blocked by XIAP [X-linked inhibitor of apoptosis protein]. This inhibition can be prevented by the release of Smac/DIABLO, which is an inhibitor of XIAP [34]. Caspase inhibiting IAPs mostly possess $\mathrm{E}_{3}$ ligase activity. Hence, they can target their apoptotic proteins for proteosomal degradation. The best examples of these are cIAP1, cIAP2 and XIAP. Smac/DIABLO directly binds to proteins and competes with the binding of IAP to caspases [35].

It has been found that NF-kB can be activated by binding of TRAIL to DR4, DR5 and DcR2. On binding of TRAIL, TRADD recruits RIP, which in turn recruits TRAF 2 . TRAF 2 is essential for the recruitment 
of IKK complex. Once IKK is activated, it phosphorylates IkB. Phosphorylation of IkB leads to its poly ubiquitation and proteosomal degradation, hence allowing the release of NF-kB [36]. A zinc finger protein called A20, is upregulated on TRAIL signalling. This protein modifies the ubiquitination pattern of RIP and causes rapid proteosomal degradation of RIP, which stops activation of NF-kB. By inhibiting the action of proteasome, IkB cannot be degraded and NF-kB is present in inactive state. This is the possbile reason for TRAIL induced apoptosis to occur. The inhibition of TRAIL induced apoptosis is mainly targeted by activation of c-FLIP by NF-kB, PKB/Akt and MAPK pathways [37]. The TRAIL signalling network has been described in detail in Figure 8.

\section{TRAIL mimetics [DR5 agonist]}

Since cancer cells have gained partial or complete resistance towards chemotherapeutic drugs, a combination of TRAIL receptor agonists with chemotherapeutic drugs can be used to induce apoptosis in different tumour cells. The effects of TRAIL can be mimicked by agonistic antibodies targeted to DR4 or DR5. Unlike TRAIL, these DR agonists do not bind to decoy receptors DcR1, DcR2 and OPG. The best example for a DR5 agonist that induces apoptosis is Conatumumab (AMG 655), a human monoclonal antibody $\left[\operatorname{IgG}_{1}\right]$ which has been targeted against human DR5. Other successful human DR5 agonistic monoclonal antibodies include HGS-ETR1 (mapatumumab), HGSTR2J and HGSETR2 (lexatumumab) [38].

Apomab, a DR5 agonistic antibody, has been used in immunotherapy and in combinatorial chemotherapy, and its anti tumour activity has been characterized invitro and in vivo. Laboratory studies have shown that Apomab initiates apoptosis through extrinsic pathway by inducing the recruitment of FADD and caspase- 8 to DR5 and form DISC as described in Figure 9 [39]. Anti TRAIL receptor antibodies are also being used for anti tumour agents, where they promote immunity mediated by T-cells [40].

(a) Before engagement by antibody, receptors (orange) are pre-

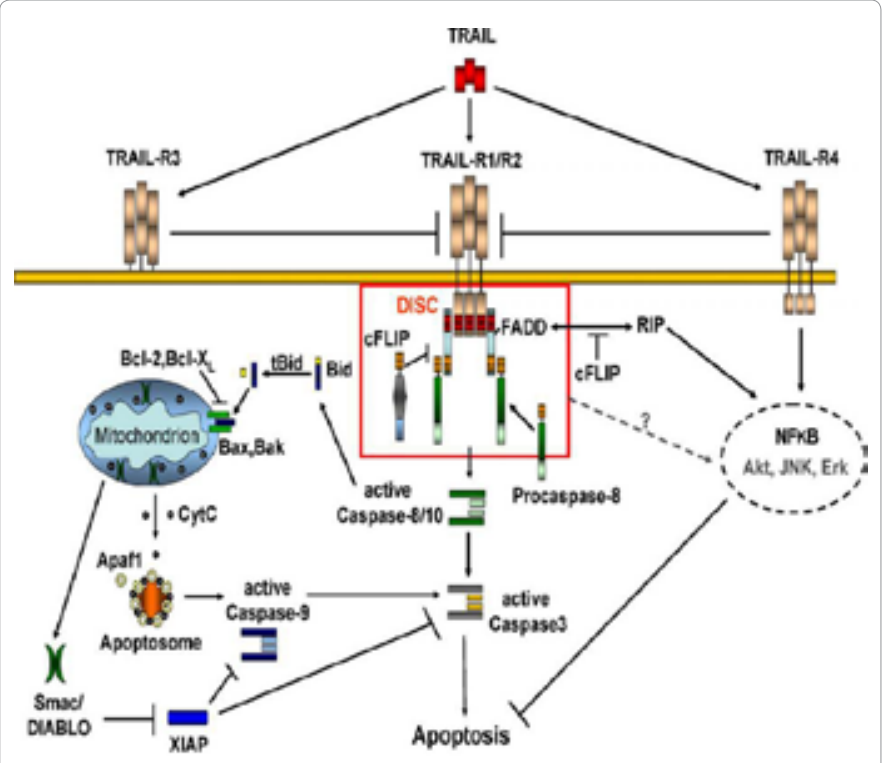

Figure 8: Scheme of the TRAIL signalling network [37]. The mechnism of action of TRAIL is the same as TNF-R1 signalling as described in figure 7. a

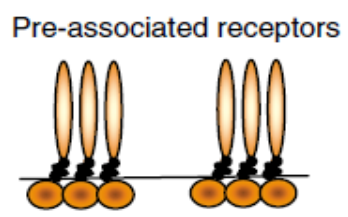

b Epitope-dependent, antibody-induced receptor clustering
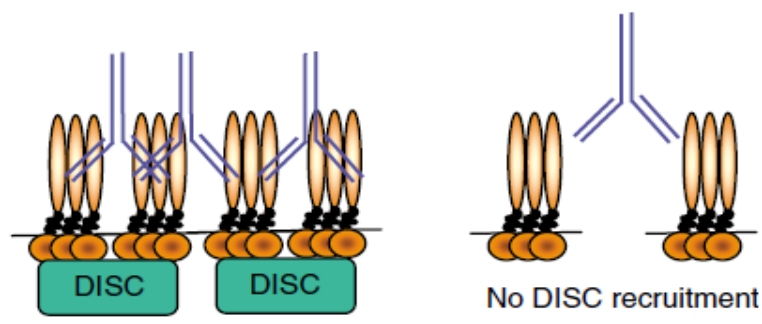

Figure 9: Model of antibody-induced DR5 signalling [39].

associated in small oligomers but nonsignaling. (b) Antibody (blue) engagement promotes clustering of pre-associated receptors, and this leads to signal-competent complexes that can recruit DISC components in an epitope-dependent manner.

In preclinical testing, recombinant soluble TRAIL has shown anti cancer activity. It has been found to induce apoptosis in a wide range of cancer cells including breast, colon, lung, prostate, kidneys, pancreatic and thyroid carcinoma. It has also been found to induce apoptosis in cell lines derived from neuro-blastoma, leukemia and multiple myeloma [41]. Response to therapeutics targeted at TRAIL receptors and chemotherapeutic response can be determined by the defects in TRAIL receptor signalling. Treatment with TRAIL can cause increased growth and metastasis in case of tumour cells that are resistant to induction of apoptosis by TRAIL. This can be explained through the fact that Binding of TRAIL to DR4 or DR5 results in the formation of DISC [Death induced silencing complex]. Then, FADD is recruited, whose death domain binds to DISC, which in turn recruits pro caspases 8 and 10. These pro caspases are then activated which transmit the apoptotic signal by activating executioner caspases. In addition to this, a zinc finger protein called A20 is upregulated on TRAIL signalling. This protein modifies the ubiquitination pattern of RIP and causes rapid proteosomal degradation of RIP, which stops activation of NF$\mathrm{kB}$. By inhibiting the action of proteasome, IkB cannot be degraded and $\mathrm{NF}-\mathrm{kB}$ is present in inactive state. This is may be the possible reason for TRAIL induced apoptosis to occur [42].

\section{Role of p53 in cell cycle and cancer}

p53 is a tumour suppressor gene that encodes p53 protein. p53 is a phosphoprotein that is produced in low levels in normal cells. It activates in response to DNA damage and initiates cell cycle arrest, senescence and programmed cell death [apoptosis] through pathways which lead of activation of p53 genes by trans-activation. p53 is involved in DNA repair process [43]. Hundreds of targets are present in the DNA for $\mathrm{p} 53$ because $\mathrm{p} 53$ is a transcription factor. The $\mathrm{p} 53$ protein binds to the promoters located near the target genes with the help of its core domain. The special characteristic activity of p53 compared to other transcription factors is that it contains a second DNA binding domain which is mapped near its C-terminus. This domain forms 
complexes with non-specific DNA targets like double stranded breaks, mismatched nucleotides, Holiday junction complexes and single stranded DNA [44]. The level of p53 protein is maintained at low levels by ubiquitin-proteasome pathway. The levels rise during cellular stress like over proliferation or DNA damage. It is activated in response to DNA damage, oxidative stress, osmotic shock, deregulated oncogenes expression and ribonucleotide depletion. These stresses increase the half life of p53 in cells and produce conformational change in p53 so that it acts as a transcriptional regulator. The first level of regulation of p53 is by MDM2 [in mice, also called as Hdm2 in humans]. MDM2 is an enzyme that covalently modifies $\mathrm{p} 53$ by addition of ubiquitin, which is then targeted to degradation by proteasome [45]. The constitutive binding of p53 to MDM2 can be explained by their gene structures as been described in Figure 10.

MDM2 generally regulates the levels of p53 in cells. It has been observed in case of one-third of sarcomas, MDM2 is amplified [ $>50$ folds] making it oncogenic. Because of its high levels, there will be a great decrease in levels of p53 resulting in loss of p53 function. Loss of 553 leads to decrease in tumour suppression, hence playing a major role in tumour development. Cells that lose p53 function continue to grow as they have the lost the apoptotic induction property [46]. Loss of p53 function of loss of p53 itself has a huge impact on the success of carcinogenic process where it increases the chances of survival of a tumour cell in adverse conditions. When p53 does not able to respond to stress signals, the cell encounters early tumour development like deregulated proliferation leading to the formation of pre neoplastic lesions. These lesions suppress the activation of p53 or block p53 activity or may alter pathways that lead to the activation of p53 leading to progression of more malignant cancers [47]. The loss of p53 leading to tumour progression is described in Figure 11 as follows:

p53 is one of the most frequently inactivated genes in cancers and most often found to be genetically altered in tumours. p53 tumour

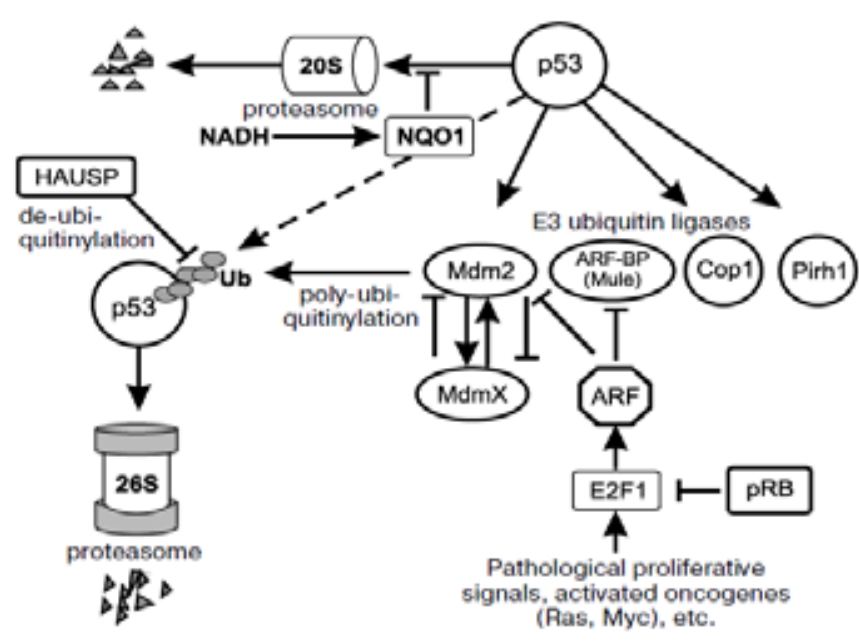

Figure 10: Regulation of degradation of $\mathrm{p} 53$ protein in proteasomes. [55] Mdm2 and $p 53$ proteins form an auto regulatory feedback loop, which controls the activities of p53. The resulting increase of p53 activity leads to upregulation of $\mathrm{Mdm2}$, and respectively, to accelerated degradation of p53 in $26 \mathrm{~S}$ proteasomes. MdmX can oligomerize with Mdm2, which leads to stabilization of Mdm2 and accelerated degradation of MdmX. Other E3 ubiquitin ligases (Cop1, Pirh2, ARF-BP/MULE, and CHIP) have been recently found to be involved in regulation of p53 levels.

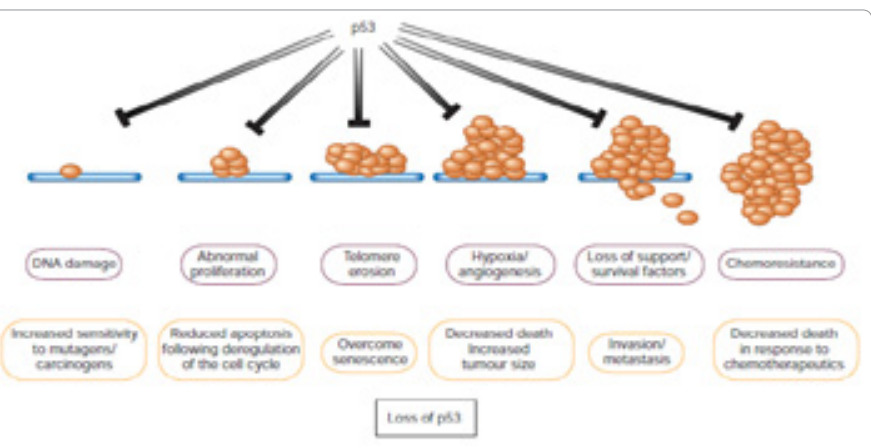

Figure 11: Events occurring due to the loss of p53 [47].

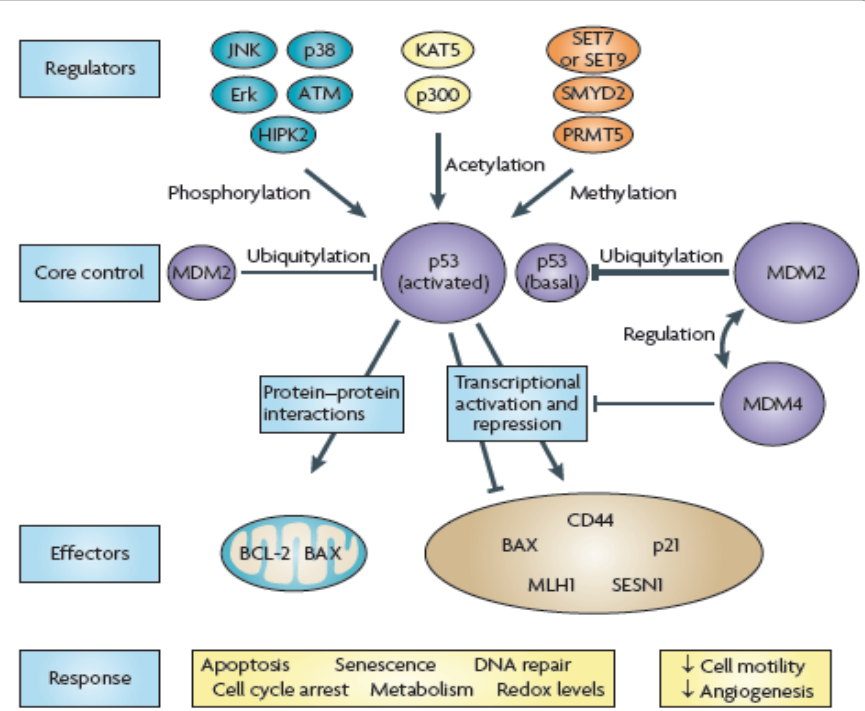

Figure 12: The p53 pathway [49]. ATM, ataxia-telangiectasia mutated; BAX, BCL-2-associated X; HIPK2, homeodomain-interacting protein kinase 2; JNK, Jun N-terminal kinase; KAT5, K (lysine) acetyl transferase 5; MLH1, MutL protein homologue 1; PRMT5, protein arginine methyl transferase 5; SESN1, sestrin 1; SMYD2, SET and MYND domain-containing 2.

suppressor function can be lost through various mechanisms like lesions preventing the activation of $\mathrm{p} 53$, mutations in downstream mediators of p53 function or mutation in TP53 itself. Cells deficient in wild type p53 are susceptible spontaneous tumorigenesis. p53 gene mutation can result in abolition of protein function and this may be linked to tumour progression and genetic instability. A logical explanation for the high frequency of the p53 mutation is that missense mutations can cause loss of tumour suppressor function and gain of oncogenic function by altering the repertoire of genes whose expression is regulated by transcription factor [48]. The p53 pathway is described in Figure 12 in detail.

p53 can be covalently modified by at least 50 different enzymes that alter its stability. As described in Figure 12, there are many activators, effectors and regulators of p53 [49].

\section{Leptomycin B}

It is a metabolite of Streptomyces that inhibits the action of CRM1 (exportin 1), a nuclear export signal receptor. CRM1 plays an important role in nuclear export of proteins in mammalian and yeast cells [50]. Leptomycin B, which was originally isolated as an anti fungal 
antibiotic from a Streptomyces strain, was found to characteristically inhibit eukaryotic cell proliferation [51]. CRM 1 is essential for the nuclear export of proteins related to cancer such as p53, FOXO-3A and c-Abl. Leptomycin specifically inhibits CRM1 in vitro but shows limited efficiency in vivo due to toxicity. When cancer cells are exposed to Leptomycin B, there is an immediate and continued block of nuclear export of $\mathrm{p} 53$, which in turn means prolonged apoptosis. Cell cycle arrest or apoptotic cell death is promoted when p53 is activated inside the nucleus. Hence, treatment of cancerous cells with Leptomycin B leads to accumulation of active p53 in the nucleus resulting in apoptosis [52]. Leptomycin has been found to irreversibly bind to CRM1 at a cysteine residue Cys528 within the cargo binding domain; hence blocking CRM1 mediated nuclear export of p53. Mutation at Cys258 in CRM1 has found to result in loss of covalent interaction and resistance towards Leptomycin B. Leptomycin B can induce arrest in cell cycle at $\mathrm{G}_{1}$ and $\mathrm{G}_{2}$ phases of cell cycle [53]. The effect of leptomycin B has been clearly explained in Figure 13.

\section{Nutlin-3a}

p53 is negatively regulated by MDM-2, an E3 ubiquitin ligase that directs $\mathrm{p} 53$ for proteosomal degradation. The amount of p53 can be increased in cancer cells by inhibiting the activity of MDM2. Nutlin

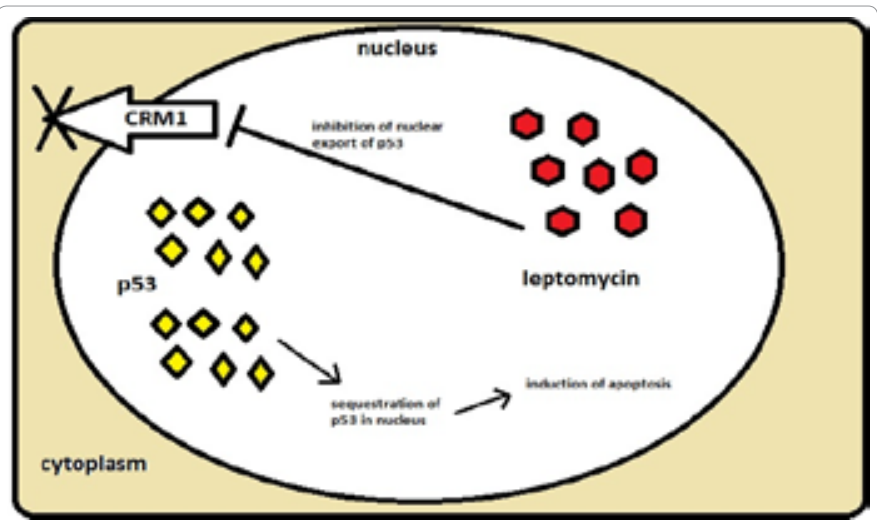

Figure 13: Effect of Leptomycin on CRM1. Leptomycin B blocks CRM1 activity, which blocks the nuclear export of p53 leading to the sequestration of p53 in nucleus, which in turn results in induction of apoptosis.

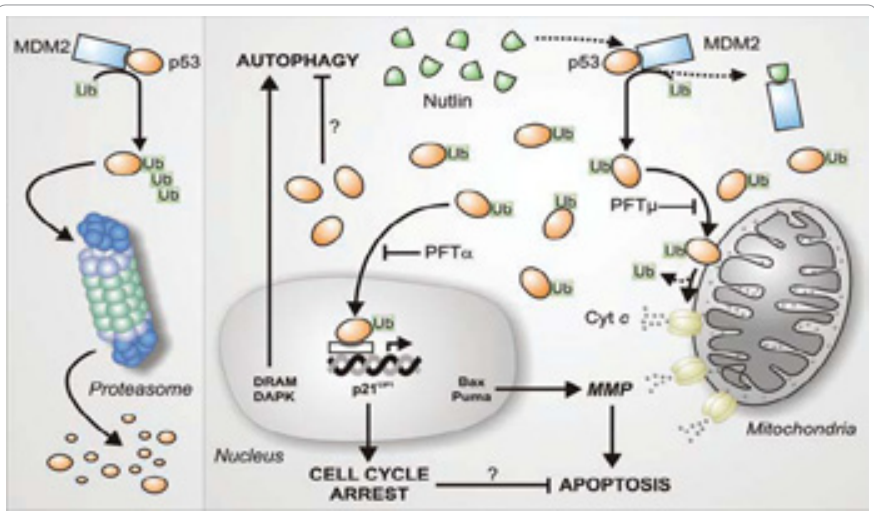

Figure 14: Nuclear vs. extra-nuclear effects of p53 stabilization [56]. MDM2 binds to p53, ubiquitinates it and leads to proteasomal degradation of p53. Nutlin, a MDM2 antagonist, binds to MDM2 and prevents it from down regulating p53 levels through proteasomal degradation, and increases levels of p53, which in turn induces apoptosis. 3a is a cis-imidiazoline that acts as a MDM2 antagonist. It releases p53 through molecular mimicry, where it competitively binds to the N-terminus of MDM2 at p53 binding hydrophobic pocket. When Nutlin binds to MDM2 irreversibly, p53 is free and can induce apoptosis in cancer cells that possess wild type p53. Apoptosis induction has not been observed in cells with mutant p53 [54]. The regulation of p53 by MDM2 and action of Nutlin has been described in Figure 14 in detail.

\section{Aims}

-To test the effects of leptomycin B, DR5 and their combination [dual treatment] on p53 +/- cells.

-To assess the effects in Nutlin 3a on dual treatments [Leptomycin $\mathrm{B}+\mathrm{DR} 5]$.

-To test the effects of leptomycin on expression of p53 related genes.

\section{Hypothesis}

Based on the previous research conducted with leptomycin B on cancer cell lines, it has been observed that leptomycin causes p53 induced apoptosis, although a percentage of cells showed p53 independent apoptosis, and some cells showed resistance against leptomycin. This project is performed to test that leptomycin B causes p53 induced apoptosis.

\section{Materials}

\section{Cell lines and materials}

The cell lines that have used for these experiments are PC3 (Human prostate cancer cell line), LNCAP [cell line of human prostate cancer] and MCF7 (human breast adenocarcinoma cell line). For culturing these cell lines, DMEM [for PC3] and RPMI-1640 [for LNCAP and MCF7] media have been used. For the preparation of complete media, penicillin/streptomycin, glutamine and foetal calf serum [FCS] have been added to the media. For passaging the cells, PBS [phosphate buffered saline] and trypsin/EDTA have been used along with T75 flasks.

\section{Materials for Hoechst staining}

For staining adherent cells for assessing apoptosis, Hoechst stain, microfuge tubes, PBS, trypsin/EDTA, DMEM or RPMI-1640 media, $4 \%$ formaldehyde and $40 \%$ glycerol have been used along with slides and coverslips.

\section{Materials for RNA isolation}

For isolation of RNA from the cells in cell lines, Tri-Reagent (Sigma T9424), pipettes, pipette tips, autoclaved micro centrifuge tube, Chloroform, Centrifuge, Isopropanol, 70\% Ethanol, RNase free water have been used.

\section{Materials for cDNA synthesis}

For synthesis of cDNA, RNase free water, $5 \mathrm{x}$ buffer, DTT, $10 \mathrm{mM}$ dNTPs, reverse transcriptase [Superscript II], random primers, autoclaved micro centrifuge tubes, micro pipettes, pipette tips, heat block $\left[42^{\circ} \mathrm{C}\right]$ and centrifuge have been used.

\section{Materials for RT-PCR}

For performing RT-PCR reaction, PCR water, 2X reaction buffer and specific primers/probes have been used for specific target genes. 


\section{Preparation of aliquots of Leptomycin B, DR5 and Nutlin}

The Leptomycin B stock was provided at $10 \mu \mathrm{M}$ concentration. The stock was diluted in cell culture media to obtain concentrations at $0.5 \mathrm{nM}, 1 \mathrm{nM}$ and $5 \mathrm{nM}$ of Leptomycin B. DR5 stock was provided at $200 \mu \mathrm{g} / \mathrm{ml}$ concentration. The stock was diluted in cell culture media to obtain concentrations of $5 \mathrm{ng} / \mathrm{ml}, 50 \mathrm{ng} / \mathrm{ml}$ and $500 \mathrm{ng} / \mathrm{ml}$ of DR5. $1 \mathrm{mg}$ of Nutlin was provided. It was dissolved in $100 \mu \mathrm{L}$ of $100 \%$ ethanol to $17 \mu \mathrm{M}$ concentration. $2.35 \mu \mathrm{L}$ of $17 \mu \mathrm{M}$ Nutlin was added to $1 \mathrm{ml}$ of cells in each well to obtain a concentration of $40 \mu \mathrm{M}$.

\section{Materials for agarose gel electrophoresis}

The materials used for performing agarose gel electrophoresis were Tris [Tris(hydroxymethyl)-methylamine], EDTA, glacial acetic acid, agarose, ethidium bromide solution $(10 \mathrm{mg} / \mathrm{ml})$, RNase free water, gel tank, gel tray, comb, rubber stoppers and power pack.

\section{Methods}

\section{Cell culture}

For passaging adherent cell lines of PC3, LNCAP and MCF7, the spent media from flask was poured in to a bleach pot. The cells were washed by adding $10 \mathrm{ml}$ PBS and the flask was gently tipped back \& forth to make sure the PBS washed over all the cells and then PBS was poured in to the bleach pot. This was done to remove the medium containing serum so that the action of trypsin is not inhibited. $3 \mathrm{ml}$ of trypsin-EDTA was added and the flask was tipped back \& forth to make sure all the cells were covered with trypsin. The cells were then incubated at $37^{\circ} \mathrm{C}$ for $5 \mathrm{mins}$ for the cells to detach. The flask was then observed under microscope to make sure all the cells had detached. Once the cells had detached from the base of the flask, a volume of media equal to the volume of trypsin was added to inhibit any further action by trypsin. Dependent on the desired split ratio, the cells in the flask were transferred to new flasks containing fresh media and incubated at $37^{\circ} \mathrm{C}$ for few days till the cell numbers increased.

\section{Plating out of cells}

For testing the effects of DR5, leptomycin B and nutlin, the cells have to be transferred to 6 and 24 well plates. For this, the cells were first counted using a haemocytometer. Based on the number of cells present, the cells were diluted to 50,000 cells $/ \mathrm{ml}$. These cells were then transferred from the flask $2 \mathrm{ml}$ in each well of a 6 well plate and $200 \mu \mathrm{L}$ in each well of a 24 well plate. These cells were incubated for 24 hours in the plates and the drugs were added after 24 hours of incubation at $37^{\circ} \mathrm{C}$.

\section{Drug treatment method}

In a batch of 6 well plates containing PC3, LNCAP and MCF7 cells, leptomycin was added at concentrations of $0.5,1$ and $5 \mathrm{nM}$; DR5 was added at concentrations of 5, 50 and $500 \mathrm{ng} / \mathrm{ml}$. To the second batch of 6 well plates, along with leptomycin and DR5, nutlin was also added at 10 and $40 \mathrm{ng} / \mathrm{ml}$. The drugs were added to the 6 and 24 well plates in the following order:

\section{4-well plate}

$\begin{array}{cccccc}\text { Leptomycin } & \text { Leptomycin } & \text { Leptomycin } & \text { Leptomycin } & \text { Leptomycin } & \text { Leptomycin } \\ 5 \mathrm{nM} & 5 \mathrm{nM} & 1 \mathrm{nM} & 1 \mathrm{nM} & 0.5 \mathrm{nM} & 0.5 \mathrm{nM} \\ \text { Leptomycin } & \text { Leptomycin } & \text { DR5 } 500 & \text { DR5 500 } & \text { DR5 50 } & \text { DR5 50 } \\ 0 \mathrm{nM} & 0 \mathrm{nM} & \mathrm{ng} / \mathrm{ml} & \mathrm{ng} / \mathrm{ml} & \mathrm{ng} / \mathrm{ml} & \mathrm{ng} / \mathrm{ml}\end{array}$

\begin{tabular}{|c|c|c|c|c|c|}
\hline DR5 $5 \mathrm{ng} / \mathrm{ml}$ & DR5 $5 \mathrm{ng} / \mathrm{ml}$ & DR5 $0 \mathrm{ng} / \mathrm{ml}$ & DR5 $0 \mathrm{ng} / \mathrm{ml}$ & $\begin{array}{c}\text { Leptomycin } \\
5 \mathrm{nM}+\mathrm{DR} 5 \\
5 \mathrm{ng} / \mathrm{ml}\end{array}$ & $\begin{array}{c}\text { Leptomycin } \\
5 \mathrm{nM}+\mathrm{DR} 5 \\
5 \mathrm{ng} / \mathrm{ml}\end{array}$ \\
\hline Leptomycin & Leptomycin & Leptomycin & Leptomycin & Leptomycin & Leptomycin \\
\hline $5 \mathrm{nM}+\mathrm{DR} 5$ & $5 \mathrm{nM}+\mathrm{DR} 5$ & $1 \mathrm{nM}+\mathrm{DR} 5$ & $1 \mathrm{nM}+\mathrm{DR} 5$ & $1 \mathrm{nM}+\mathrm{DR} 5$ & $1 \mathrm{nM}+\mathrm{DR} 5$ \\
\hline $50 \mathrm{ng} / \mathrm{ml}$ & $50 \mathrm{ng} / \mathrm{ml}$ & $5 \mathrm{ng} / \mathrm{ml}$ & $5 \mathrm{ng} / \mathrm{ml}$ & $50 \mathrm{ng} / \mathrm{ml}$ & $50 \mathrm{ng} / \mathrm{ml}$ \\
\hline
\end{tabular}

$\begin{array}{lll}\text { Control } & \text { Leptomycin } 1 \mathrm{nM} & \text { Leptomycin } 5 \mathrm{nM} \\ \text { DR5 } 50 \mathrm{ng} / \mathrm{ml} & \text { Leptomycin } 1 \mathrm{nM}+\text { DR5 Leptomycin } 5 \mathrm{nM}+\text { DR5 } \\ & 50 \mathrm{ng} / \mathrm{ml} & 50 \mathrm{ng} / \mathrm{ml}\end{array}$

6 well plate assay [Nutlin treatment]

\begin{abstract}
Control Control + Nutlin Leptomycin $1 \mathrm{nM}+\mathrm{DR} 525 \mathrm{n} \mathrm{ng} / \mathrm{ml}+$ Nutlin
Leptomycin $1 \mathrm{nM}$ DR5 $25 \mathrm{ng} / \mathrm{ml} \quad$ Leptomycin $1 \mathrm{nM}+\mathrm{DR} 525 \mathrm{n} \mathrm{ng} / \mathrm{ml}$

Control Control + Nutlin Leptomycin $5 \mathrm{nM}+\mathrm{DR} 525 \mathrm{ng} / \mathrm{ml}+$ Nutlin

Leptomycin 5 nM DR5 $25 \mathrm{ng} / \mathrm{ml} \quad$ Leptomycin $5 \mathrm{nM}+$ DR5 25n ng/ml
\end{abstract}

\section{Hoechst staining for assessment of apoptosis}

Once the cells had been treated with drug for 24 hours in a well plate, medium was removed and placed in a microfuge tube. The well was washed with $0.3 \mathrm{ml}$ PBS and combined with medium in microfuge tube. $0.2 \mathrm{ml}$ of trypsin was added to each well for the cells to detach. The well was the washed $0.3 \mathrm{ml}$ medium and the contents were transferred into microfuge tube. The microfuge tubes were then centrifuged at 2000rpm for 3 minutes. The supernatant was discarded and nearly $100 \mu \mathrm{L}$ was left in each tube. $0.4 \mathrm{ml}$ of $4 \%$ formaldehyde was then added to the supernatants and mixed well. These were then cytospinned onto microscope slides by adding $150 \mu \mathrm{L}$ of cell suspension to the funnel and spinning at $500 \mathrm{rpm}$ for 5 minutes. After cytospin, a drop of Hoechst stain was added to the cells on the slide and left for 5 minutes. Then, a drop of $40 \%$ glycerol was added and a coverslip was placed. The images were then captured on fluorescence microscope.

\section{Calculation of $\%$ apoptosis}

For calculating the percentage [\%] apoptosis, 150 cells were counted per each slide. Percentage apoptosis was calculated as follows:

\section{$\%$ apoptosis=Number of apoptotic cells $\div 150 \times 100$}

\section{RNA isolation}

After treating the cell lines on a 24 well plate with Leptomycin B and DR5, the cells were lysed directly on culture dish. Then, $0.5 \mathrm{ml}$ of Tri Reagent was added to each well. The cell scraper was used to scrape off the cells and the cell lysate was passed through pipette several times to form homogeneous lysate. The lysate was then transferred to $1.5 \mathrm{ml}$ micro centrifuge tube. $0.2 \mathrm{ml}$ of chloroform was added. And the sample was vortexed for few seconds. The resulting mixture was the centrifuged at $12,000 \mathrm{rpm}$ for 15 minutes at $4^{\circ} \mathrm{C}$ which separated the mixture into 3 phases: a red organic phase (protein) in the bottom, an interphase pellet (DNA) in the middle, and a colourless aqueous phase (RNA) at the top. The top aqueous phase was transferred to a new autoclaved micro centrifuge tube and $0.5 \mathrm{ml}$ of isopropanol was added. The sample was mixed well and allow sample to stand for few minutes. The sample was then centrifuge at $12,000 \mathrm{~g}$ for 10 minutes at $4^{\circ} \mathrm{C}$. The RNA precipitated in the form of a pellet at the bottom of the tube. The supernatant was removed and RNA pellet was washed by filling tube with $75 \%$ ethanol. The sample was vortexed and then centrifuged at 
$7,500 \mathrm{~g}$ for 5 minutes at $4^{\circ} \mathrm{C}$. The ethanol was then poured out and tubes were placed upside down on filter paper to get rid of traces of ethanol. But the RNA pellet was not allowed to dry completely. $50 \mu \mathrm{L}$ of RNase free water was then added to RNA pellet and the tubes were then stored at $4^{\circ} \mathrm{C}$.

\section{Agarose gel electrophoresis}

Preparation of TAE [Tris-acetate-EDTA] buffer: $46.46 \mathrm{~g}$ Tris [Tris (hydroxymethyl)-methylamine] was weighed and $800 \mathrm{ml}$ of deionised water was added to it. $20 \mathrm{ml}$ of $500 \mathrm{mM}$ EDTA solution was then added to it. $11.4 \mathrm{ml}$ of Glacial Acetic Acid was then slowly added. Then, the solution was made up to 1 liter with deionised water. This produced the 10X running buffer. The running buffer was diluted to $1 \mathrm{X}$ before use by addition of $50 \mathrm{ml}$ of $10 \mathrm{X}$ buffer to $450 \mathrm{ml}$ of deionised water.

Preparation of agarose gel: For preparing a 1\% pre-stained gel, $300 \mathrm{mg}$ of agarose was weighed out in a $100 \mathrm{ml}$ conical flask. $30 \mathrm{ml}$ of 1X TAE buffer was added and mixed by swirling. The flask was covered with foil and placed in a steamer for melting the agarose. Once melted, the gel was cooled slightly and $3 \mu \mathrm{l}$ of $10 \mathrm{mg} / \mathrm{ml}$ ethidium bromide was added in the fume hood. The gel solution was then poured into a gel mould with end blocks, the comb was inserted and the gel was left to set. Once the gel had solidified, the end blocks and the comb were removed. The gel with the tray was then placed into the electrophoresis tank in a manner that the wells were at the negative end. The tank was then filled with 1X TAE buffer until the gel was completely covered, which requires around $300 \mathrm{ml}$ of the $1 \mathrm{X}$ buffer.

Electrophoresis: $8 \mu \mathrm{l}$ of each RNA sample that were isolated was mixed with $2 \mu \mathrm{l}$ of loading buffer. In the $1^{\text {st }}$ well/lane in the gel, a molecular weight marker was loaded. The samples then were carefully pipetted and loaded into the remaining wells of the gel, without puncturing the gel. The gel tank was assembled and electrophoresed at $100 \mathrm{~V}$ till the dye almost reached the end. This is performed to confirm the presence of RNA that has been derived through reverse transcription and that the RT-PCR results are not false.

\section{cDNA synthesis [Reverse transcription]}

To determine whether the target genes are being expressed in the target cells, the RNA has to be converted to cDNA so that it can be used as the template in RT-PCR, in which the target genes can be amplified and their expression levels or presence can be determined. To obtain a $20 \mu \mathrm{l}$ reaction mixture for cDNA synthesis, the following components were added:

$\begin{array}{lc}\text { PCR water } & -7.5 \mu \mathrm{L} \\ \text { 5X buffer } & -4 \mu \mathrm{L} \\ \text { DTT } & -2 \mu \mathrm{L} \\ \text { dNTPs } & -0.5 \mu \mathrm{L}\end{array}$

Random primers - $0.5 \mu \mathrm{L}$

Reverse transcriptase $-0.5 \mu \mathrm{L}$

RNA [specific for each tube] $-5 \mu \mathrm{L}$

The reaction mixture containing tubes were then placed in a heating block set at $42^{\circ} \mathrm{C}$ for 90 minutes.

\section{RT-PCR}

To obtain an $18 \mu \mathrm{L}$ master mix for each cDNA sample, the following components were added:

$$
\begin{array}{lr}
\text { 2X buffer } & -10 \mu \mathrm{L} \\
\text { PCR water } & -7 \mu \mathrm{L}
\end{array}
$$

Primer/probe [varies for each target gene] $-1 \mu \mathrm{L}$

To each tube containing $18 \mu \mathrm{L}$ of master mix, $2 \mu \mathrm{L}$ of cDNA was added. From the total volume of $20 \mu \mathrm{L}$ in each tube, $10 \mu \mathrm{L}$ was added to each well in PCR plate. The plate was then placed in the RT-PCR apparatus [Step One system-Applied Biosystems] and run for 40 minutes to check for levels of gene expression for specific genes. The primers/probes that were used to check the levels of gene expression were HPRT, DR4, DR5, DcR1, DcR2, c-FLIP, BIRC3 and BIRC4.

\section{Calculation of $\mathrm{C}_{t}$ value [Efficiency method]}

In RT-PCR, the cycle number at which the increase in fluorescence (i.e. cDNA) is exponential is measured. This increase point in fluorescence is known as the threshold and is set by the user. The point at which the fluorescence crosses the threshold is called the ' $\mathbf{C}_{\mathbf{t}}$ '. The difference between the $\mathrm{C}_{t}$ value of target and reference sample is called $\Delta \mathrm{C}_{\mathrm{t}}\left[\right.$ delta $\left.\mathrm{C}_{\mathrm{t}}\right]$.

\section{$\Delta \mathrm{C}_{\mathrm{t}}$ [control $]=\mathrm{C}_{\mathrm{t}}$ [target gene $]-\mathrm{C}_{\mathrm{t}}$ [reference gene $]$}

Once the reference and the target genes are treated with a drug, the $\mathrm{C}_{\mathrm{t}}$ values of the treated samples are determined.

\section{$\Delta \mathrm{C}_{\mathrm{t}}$ [treated] $=\mathrm{C}_{\mathrm{t}}$ [treated target gene] $-\mathrm{C}_{\mathrm{t}}$ [treated reference gene]}

Once calculated, the difference between the treated and the control samples gives the $\Delta \Delta \mathbf{C}_{\mathrm{t}}$ [delta-delta $\mathrm{C}_{\mathrm{t}}$ ].

\section{$\Delta \Delta \mathrm{C}_{\mathrm{t}}=\Delta \mathrm{C}_{\mathrm{t}}$ [treated] $-\Delta \mathrm{C}_{\mathrm{t}}$ [control]}

$\Delta \Delta \mathrm{C}_{\mathrm{t}}$ value is useful to exhibit the relative comparison in the expression of the genes under different conditions.

The final step of efficiency method involves the calculation of relative gene expression and this is determined by calculating the value of $2^{-\Delta \Delta \mathrm{Ct}}$ [2-delta-delta Ct$]$. A positive value of $2^{-\Delta \Delta \mathrm{Ct}}$ indicates an increase in gene expression whereas a negative value indicates a decrease in gene expression.

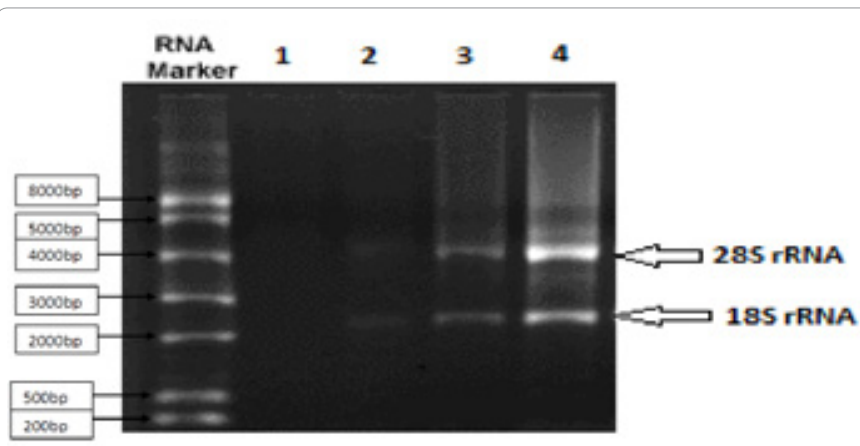

Figure 15: Gel picture showing the bands of RNA which have separated into $28 \mathrm{~S}$ and $18 \mathrm{~S} \mathrm{rRNA}$. [1=500ng/ml DR5, 2= 50ng/mIDR5, 3= $1 \mathrm{nM} \mathrm{LMB,} \mathrm{4=}$ Control sample]. 


\section{Results}

\section{RNA gel electrophoresis}

This electrophoresis step is performed to confirm the presence of RNA in the tubes containing cancer cells that have been subjected to RNA isolation procedure [Tri-reagent method]; so that they can be reverse transcribed to cDNA and can be checked for level of gene expression in RT-PCR. The gel picture depicting the presence of RNA has been shown in Figure 15 as follows;

\section{Effect of Leptomycin, DR5 and dual treatment on PC3 cells}

In this experiment, PC3 cells were plated at 50,000 cells $/ \mathrm{ml}$ and incubated for 5 hours. After incubation, these cells were treated with varying concentrations of leptomycin B, DR5 and their combinations [as described in drug treatment methods] and incubated for 24 hours to check the percentage of apoptotic cells. After 24 hours of incubation, cells from each well were stained using Hoechst stain and viewed under

\begin{tabular}{|l|l|}
\hline PC3 24-well plate assay & \\
\hline DRUG & \% Apoptosis \\
\hline LM $0 \mathrm{nM}$ & 5.67 \\
\hline LM $0.5 \mathrm{nM}$ & 12 \\
\hline LM $1 \mathrm{nM}$ & 22 \\
\hline LM $5 \mathrm{nM}$ & 36.67 \\
\hline DR5 $0 \mathrm{ng} / \mathrm{ml}$ & 10 \\
\hline DR5 $5 \mathrm{ng} / \mathrm{ml}$ & 32 \\
\hline DR5 $50 \mathrm{ng} / \mathrm{ml}$ & 50.67 \\
\hline DR5 $500 \mathrm{ng} / \mathrm{ml}$ & 68.67 \\
\hline LM $1+$ DR5 $5 \mathrm{ng} / \mathrm{ml}$ & 41.33 \\
\hline LM $5+$ DR5 $5 \mathrm{ng} / \mathrm{ml}$ & 48.67 \\
\hline LM $1+$ DR5 $50 \mathrm{ng} / \mathrm{ml}$ & 65.33 \\
\hline LM $5+$ DR5 $50 \mathrm{ng} / \mathrm{ml}$ & 81.33 \\
\hline
\end{tabular}

Table 1: Effect of leptomycin [LM], DR5 and their combined effects in an order of increasing concentrations on PC3 cells. The PC 3 cells were plated at 50,000cells/ $\mathrm{ml}$ in a 24 well plate and were treated with varying concentrations of leptomycin B, DR5 and their combinations. After an incubation period of 24 hours, these cells were stained and counted using Hoechst stain by fluorescence microscopy.

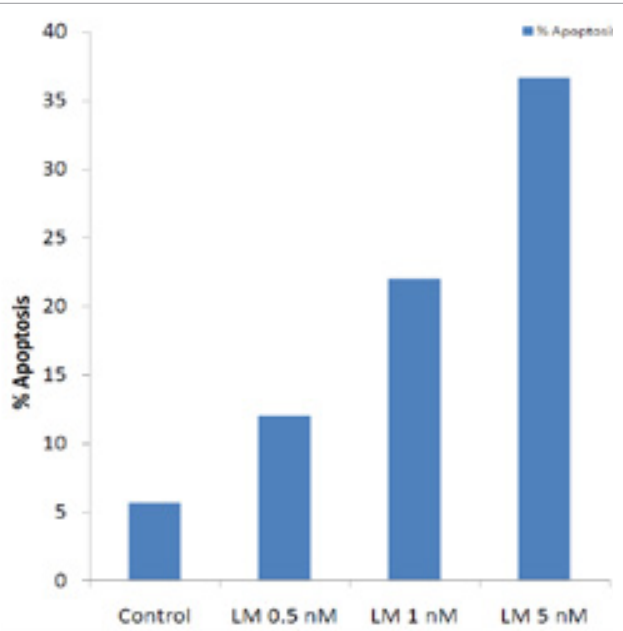

Figure 16: Effect of varying concentrations of Leptomycin B on PC3 cells. This graph depicts \% apoptosis based on varying concentrations of leptomycin B [LMB] on PC3 cells. These PC3 cells were incubated for 24 hours after addition of varying concentrations of leptomycin B and stained to check for the percentage of apoptotic cells.

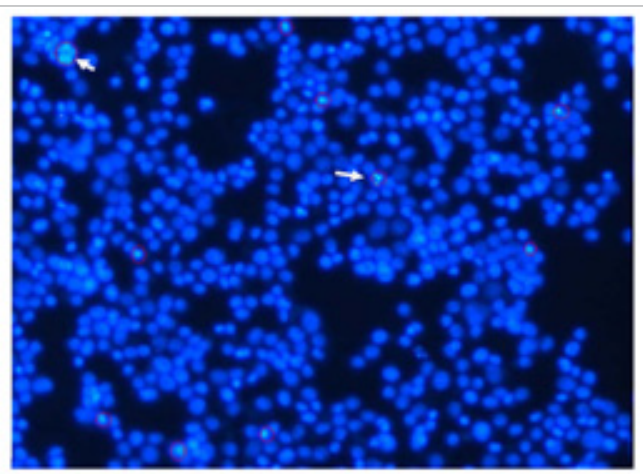

Figure 17: Control sample of PC3 cells captured through fluorescent imaging. Apoptotic cells [bright spots] have been indicated with white arrows. In this the cells have not been treated with any drug and have been used as control sample in the experiment.

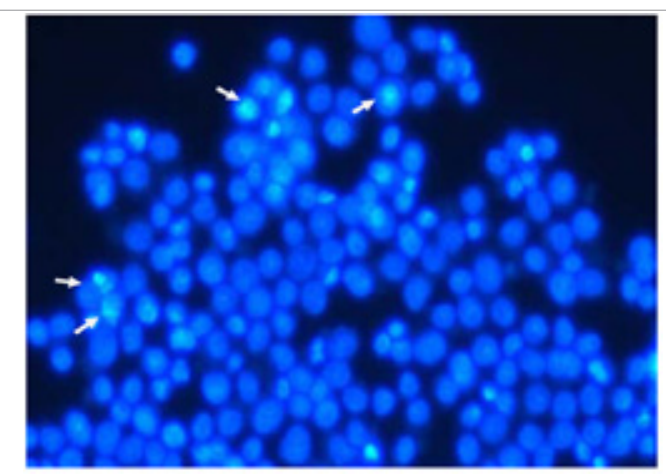

Figure 18: $\mathrm{PC} 3$ cells treated with $0.5 \mathrm{nM}$ leptomycin captured through fluorescent imaging. Apoptotic cells [bright spots] have been indicated with white arrows. In this case, the PC3 cells were treated with $0.5 \mathrm{nM}$ LMB and were incubated for 24 hours before being stained. The treatment with $0.5 \mathrm{nM}$ LMB obtained $12 \%$ of apoptotic cells.

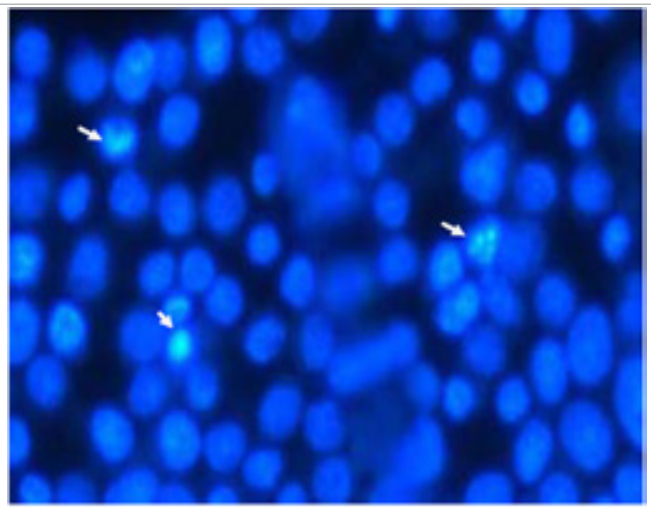

Figure 19: PC3 cells treated with 1nM leptomycin captured through fluorescent imaging. Apoptotic cells [bright spots] are indicated with white arrows. In this case, the PC3 cells were treated with $1 \mathrm{nM}$ LMB and were incubated for 24 hours before being stained. The treatment with $1 \mathrm{nM}$ LMB obtained $22 \%$ of apoptotic cells.

fluorescent microscope at 10X magnification to count the number of apoptotic cells. Based on the results obtained, it can be observed that although PC3 cells are p53 null mutants, the number of apoptotic cells formed on treatment with $0.5,1$ and $5 \mathrm{nM}$ concentrations of leptomycin B were 12, 22 and $36.67 \%$ respectively, which means that the anti cancer effects of leptomycin are not completely p53 dependent. 


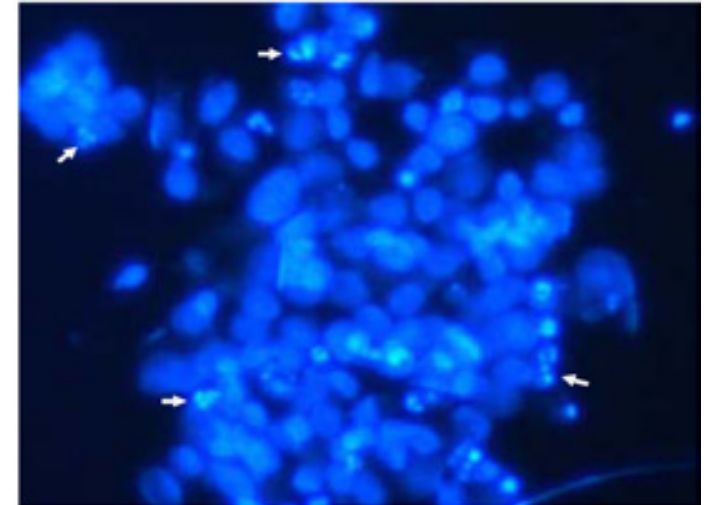

Figure 20: $\mathrm{PC} 3$ cells treated with $5 \mathrm{nM}$ leptomycin captured through fluorescent imaging. Apoptotic cells [bright spots] have been indicated with white arrows. In this case, the PC3 cells were treated with 5nM LMB and were incubated for 24 hours before being stained. The treatment with $5 \mathrm{nM} \mathrm{LMB}$ obtained $36.67 \%$ of apoptotic cells.

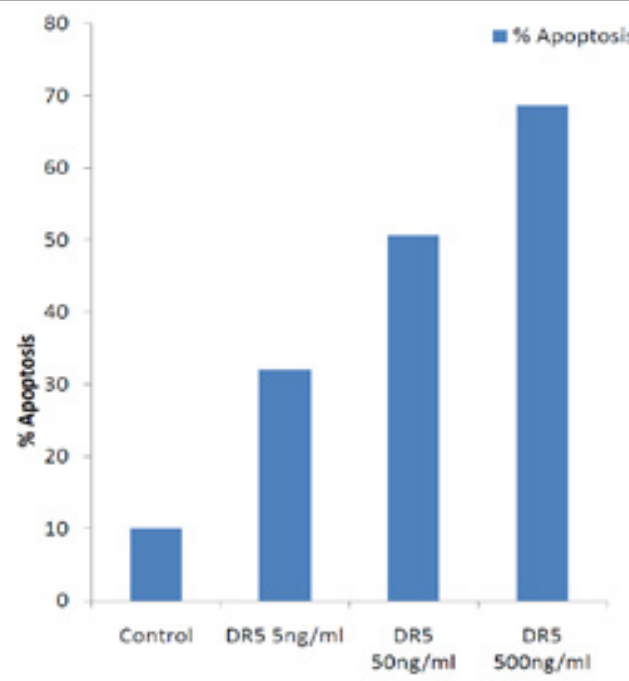

Figure 21: Effect of DR5 on PC3 cells. This graph depicts \% apoptosis based on varying concentrations of DR5 on PC 3 cells. These PC 3 cells were incubated for 24 hours after addition of varying concentrations of DR5 and stained to check for the percentage of apoptotic cells.

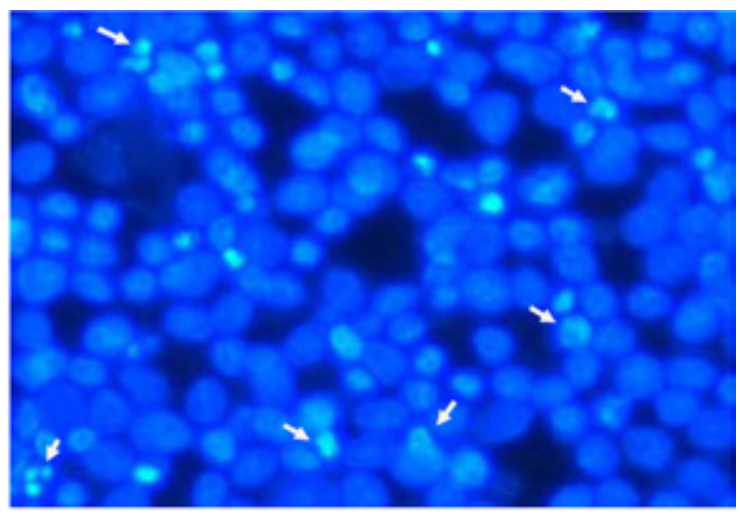

Figure 22: PC3 cells treated with $5 \mathrm{ng} / \mathrm{ml}$ DR5 captured through fluorescent imaging. Apoptotic cells [bright spots] have been indicated with white arrows. In this case, the PC 3 cells were treated with $5 \mathrm{ng} / \mathrm{ml}$ DR5 and were incubated for 24 hours before being stained. The treatment with $5 \mathrm{ng} / \mathrm{ml}$ DR5 obtained $32 \%$ of apoptotic cells.

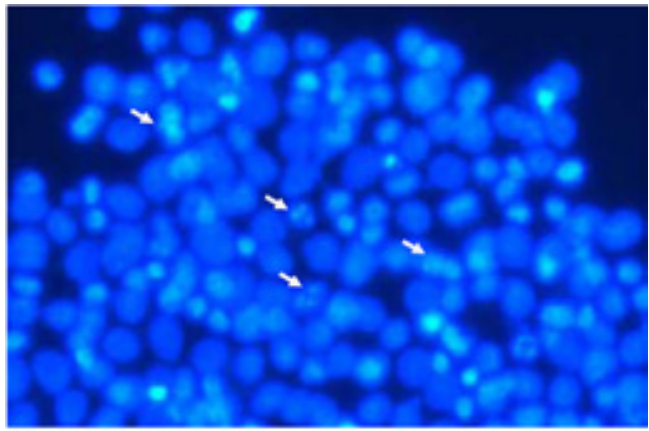

Figure 23: PC3 cells treated with 50ng/ml DR5 captured through fluorescent imaging. Apoptotic cells [bright spots] have been indicated with white arrows. In this case, the PC3 cells were treated with $50 \mathrm{ng} / \mathrm{ml}$ DR5 and were incubated for 24 hours before being stained. The treatment with $50 \mathrm{ng} / \mathrm{ml}$ DR5 obtained $50.67 \%$ of apoptotic cells.

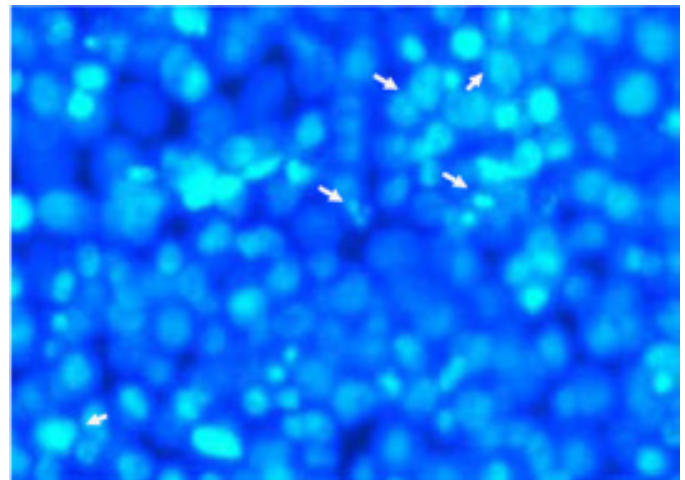

Figure 24: PC3 cells treated with 500ng/ml DR5 captured through fluorescent imaging. Apoptotic cells [bright spots] have been indicated with white arrows. In this case, the PC 3 cells were treated with $500 \mathrm{ng} / \mathrm{ml}$ DR5 and were incubated for 24 hours before being stained. The treatment with $500 \mathrm{ng} / \mathrm{ml}$ DR5 obtained $68.67 \%$ of apoptotic cells

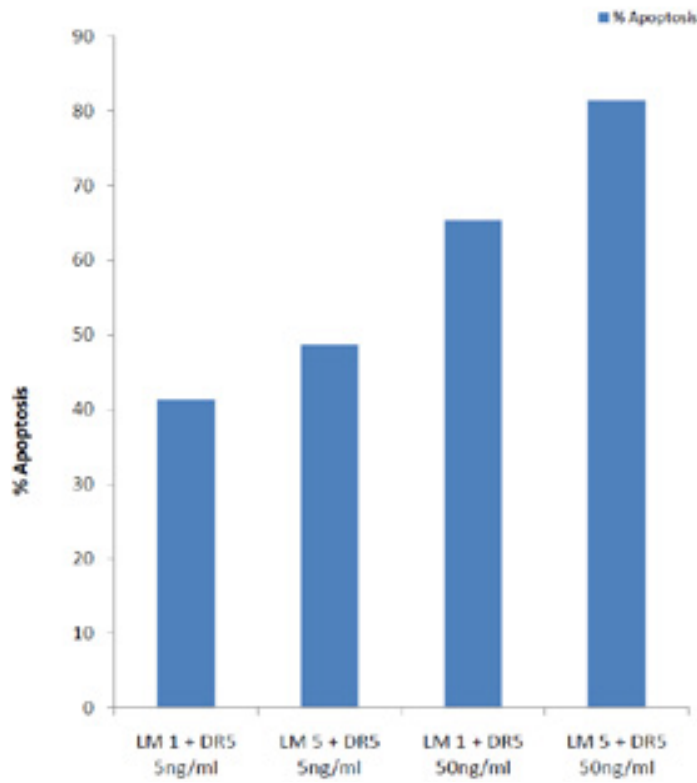

Figure 25: Effect of dual treatment [Leptomycin B + DR5] on PC3 cells. This graph depicts \% apoptosis based on varying combined concentrations of Leptomycin B [LMB] and DR5 on PC3 cells. These PC3 cells were incubated for 24 hours after addition of varying concentrations of Leptomycin B + DR5 stained to check for the percentage of apoptotic cells. 


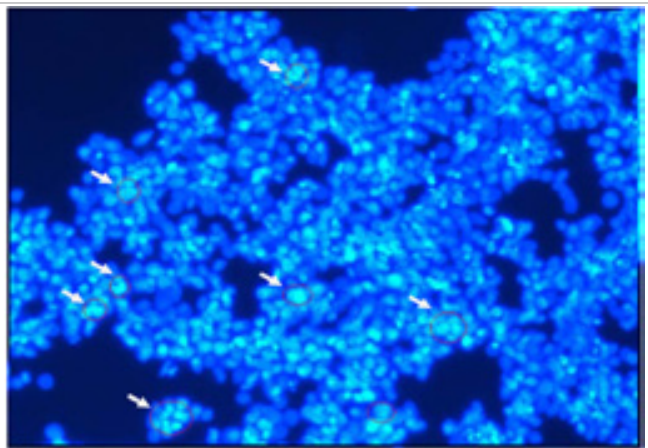

Figure 26: PC3 cells treated with $1 \mathrm{nM}$ leptomycin $+5 \mathrm{ng} / \mathrm{ml}$ DR5 captured through fluorescent imaging. Apoptotic cells [bright spots] have been indicated with white arrows. In this case, the PC 3 cells were treated with $1 \mathrm{nM}$ leptomycin $+5 \mathrm{ng} / \mathrm{ml}$ DR5 and were incubated for 24 hours before being stained. The treatment with $1 \mathrm{nM}$ leptomycin $+5 \mathrm{ng} / \mathrm{ml}$ DR5 obtained $41.33 \%$ of apoptotic cells.

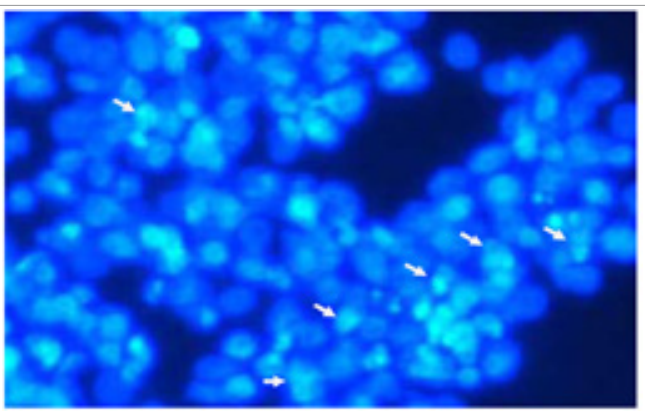

Figure 27: PC3 cells treated with $1 \mathrm{nM}$ leptomycin $+50 \mathrm{ng} / \mathrm{ml}$ DR5 captured through fluorescent imaging. Apoptotic cells [bright spots] have been indicated with white arrows. In this case, the PC3 cells were treated with $1 \mathrm{nM}$ leptomycin $+50 \mathrm{ng} / \mathrm{ml}$ DR5 and were incubated for 24 hours before being stained. The treatment with $1 \mathrm{nM}$ leptomycin $+50 \mathrm{ng} / \mathrm{ml}$ DR5 obtained $48.67 \%$ of apoptotic cells.

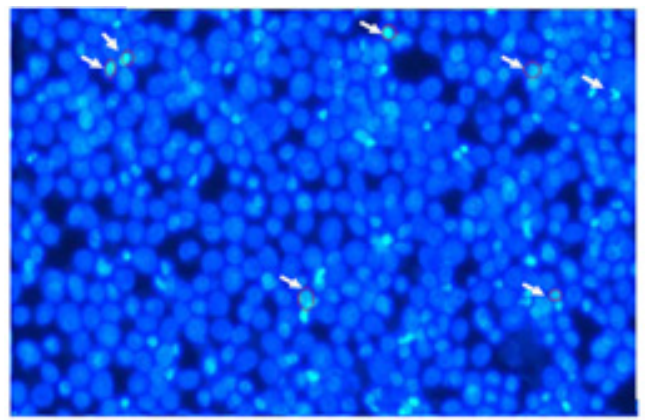

Figure 28: PC3 cells treated with $5 \mathrm{nM}$ leptomycin $+5 \mathrm{ng} / \mathrm{ml}$ DR5 captured through fluorescent imaging. Apoptotic cells [bright spots] have been indicated with white arrows. In this case, the PC 3 cells were treated with $5 \mathrm{nM}$ leptomycin $+5 \mathrm{ng} / \mathrm{ml}$ DR5 and were incubated for 24 hours before being stained. The treatment with $5 \mathrm{nM}$ leptomycin $+5 \mathrm{ng} / \mathrm{ml}$ DR5 obtained $65.33 \%$ of apoptotic cells.

Varying concentrations of DR5 have yielded percentage of apoptotic cells in the range of 32 to $68.67 \%$. In case of dual treatment, leptomycin B has enhanced the percentage of apoptotic cells by $10-20 \%$ when combined with DR5 ranging from 41 to $81 \%$ in varying concentrations, although PC3 cells are p53 deficient.

The results of this experiment have been described in Table 1, and as graphs and images in Figures 16-29.

\section{Effect of Nutlin on PC3 cells}

In this experiment, a 6-well plate was plated with PC3 cells at a density of 10,000 cells/ml and incubated for 24 hours. After incubation, the cells were treated with Nutlin 3 a for 5 hours followed by addition of leptomycin B, DR5 and their combination in varying concentrations in respective wells [as described in drug treatment method] and incubated for 24 hours. Images were captured under light microscope before treatment and after 24 hour incubation of treated cells to calculate the number of missing cells which in turn indicates the number of apoptotic cells, to calculate the percentage of apoptotic cells. Nutlin was added to cells treated with dual treatment [Leptomycin B + DR5] to test whether it enhances the percentage of apoptotic cells. Since nutlin blocks the export of p53 from nucleus, its anti cancer effects are p53 dependent. But when Nutlin was added to PC3 cells [p53 null

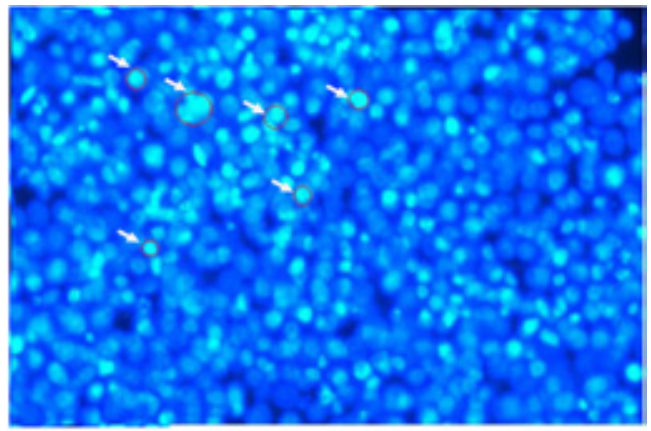

Figure 29: PC3 cells treated with $5 \mathrm{nM}$ leptomycin + 50ng/ml DR5 captured through fluorescent imaging. Apoptotic cells [bright spots] have been indicated with white arrows. In this case, the PC 3 cells were treated with $5 \mathrm{nM}$ leptomycin $+50 \mathrm{ng} / \mathrm{ml} \mathrm{DR5}$ and were incubated for 24 hours before being stained. The treatment with $5 \mathrm{nM}$ leptomycin $+50 \mathrm{ng} / \mathrm{ml}$ DR5 obtained $81.33 \%$ of apoptotic cells.

\begin{tabular}{|l|l|}
\hline DRUG & \% Apoptosis \\
\hline Control & 4.5 \\
\hline LM $0.5 \mathrm{nM}$ & 12 \\
\hline LM $1 \mathrm{nM}$ & 22 \\
\hline DR5 $25 \mathrm{ng} / \mathrm{ml}$ & 33.5 \\
\hline LM $0.5 \mathrm{nM}+$ DR5 $25 \mathrm{ng} / \mathrm{ml}$ & 45.5 \\
\hline LM $1 \mathrm{nM}+$ DR5 $25 \mathrm{ng} / \mathrm{ml}$ & 51 \\
\hline
\end{tabular}

Table 2: Effect of leptomycin, DR5 and their combination in varying concentrations on PC3 cells. The PC3 cells were plated at $10,000 \mathrm{cells} / \mathrm{ml}$ in a 6 well plate and incubated for 24 hours. These were then treated with varying concentrations of leptomycin B, DR5 and their combinations and incubated for 24 hours. Images of cells were captured before and after incubation with drugs through light microscopy for calculating percentage apoptosis.

\begin{tabular}{|l|l|}
\hline DRUG & \% Apoptosis \\
\hline Control & 4.5 \\
\hline Control+ Nutlin & 37 \\
\hline LM $0.5 \mathrm{nM}+$ DR5 $25 \mathrm{ng} / \mathrm{ml}$ & 45.5 \\
\hline LM $1 \mathrm{nM}+$ DR5 $25 \mathrm{ng} / \mathrm{ml}$ & 51 \\
\hline LM $0.5 \mathrm{nM}+$ DR5 $25 \mathrm{ng} / \mathrm{ml}+$ Nutlin & 52.5 \\
\hline LM $1 \mathrm{nM}+$ DR5 $25 \mathrm{ng} / \mathrm{ml}+$ Nutlin & 57 \\
\hline
\end{tabular}

Table 3: Effect of nutlin on combination of varying concentrations of leptomycin and DR5 on PC 3 cells- The PC 3 cells were plated at 10,000 cells $/ \mathrm{ml}$ in a 6 well plate and incubated for 24 hours. These were then treated with nutlin and incubated for 5 hours followed by addition of varying concentrations of leptomycin B, DR5 and their combinations and incubated for 24 hours. Images of cells were captured before and after incubation with drugs through light microscopy for calculating percentage apoptosis. 


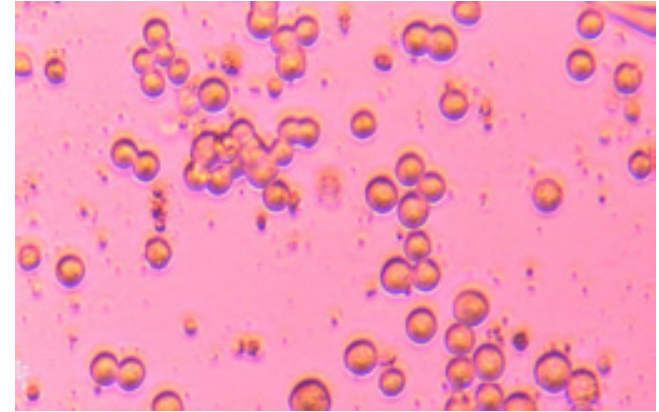

Figure 30: PC3 cells treated with nutlin [0 hours]. This picture depicts a section of PC3 cells at a density of 10,000 cells $/ \mathrm{ml}$ that have been treated with nutlin and have not been incubated.

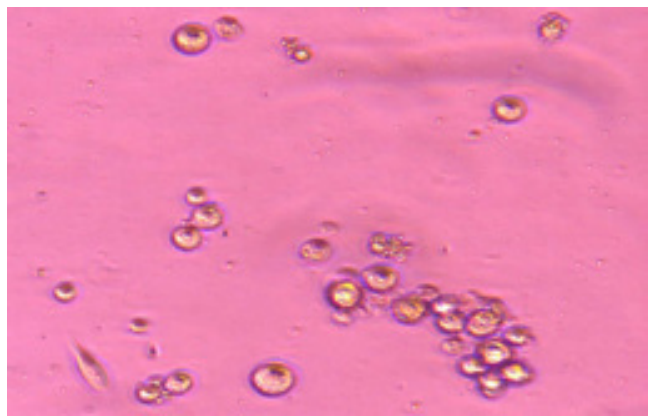

Figure 31: PC3 cells treated with nutlin [24 hours]. This picture depicts the same section of PC3 cells from figure 32 that have been incubated for 24 hours after treatment with nutlin. The percentage of apoptosis was found to be $37 \%$.

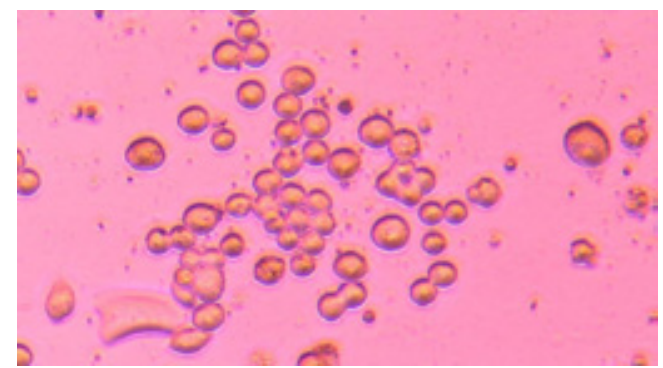

Figure 32: PC3 cells treated with 1nM leptomycin+ 25ng/ml DR5 +nutlin [0 hours]. This picture depicts a section of PC3 cells at a density of 10,000 cells/ $\mathrm{ml}$ that have been treated with nutlin for 5 hours followed by addition of $1 \mathrm{nM}$ leptomycin $+25 \mathrm{ng} / \mathrm{ml} \mathrm{DR5}$ and have not been incubated.

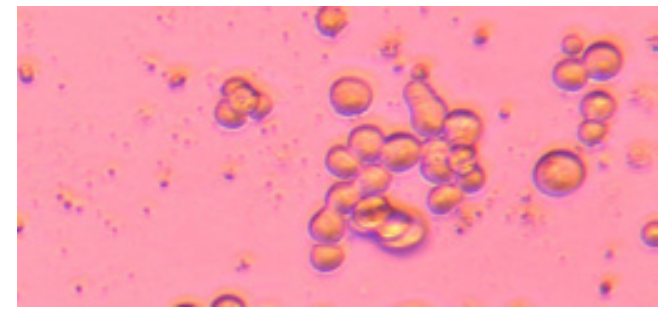

Figure 33: PC3 cells treated with $1 \mathrm{nM}$ leptomycin+25ng/ml DR5+nutlin [24 hours]. This picture depicts the same section of PC3 cells from figure 32 that have been incubated for 24 hours after treatment with $1 \mathrm{nM}$ leptomycin $+25 \mathrm{ng} / \mathrm{ml}$ DR5+nutlin. The percentage of apoptosis was found to be $57 \%$.

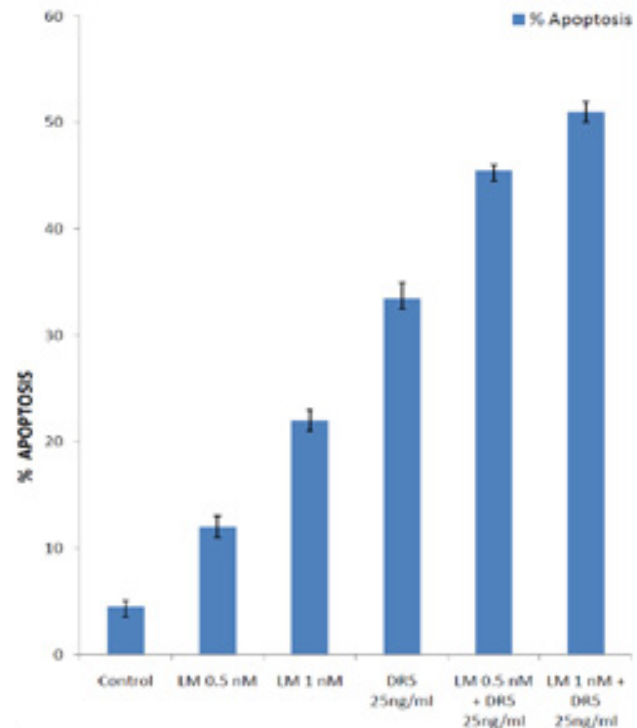

Figure 34: Effect of leptomycin and DR5 on PC3 cells. This graph depicts the effect of leptomycin, DR5 and their combination in varying concentrations on PC3 cells. In this experiment, PC3 cells were plated at 10,000cells $/ \mathrm{ml}$ in a 6 well plate and incubated for 24 hours. These were then treated with varying concentrations of leptomycin B, DR5 and their combinations and incubated for 24 hours. Images of cells were captured before and after incubation with drugs through light microscopy for calculating percentage apoptosis

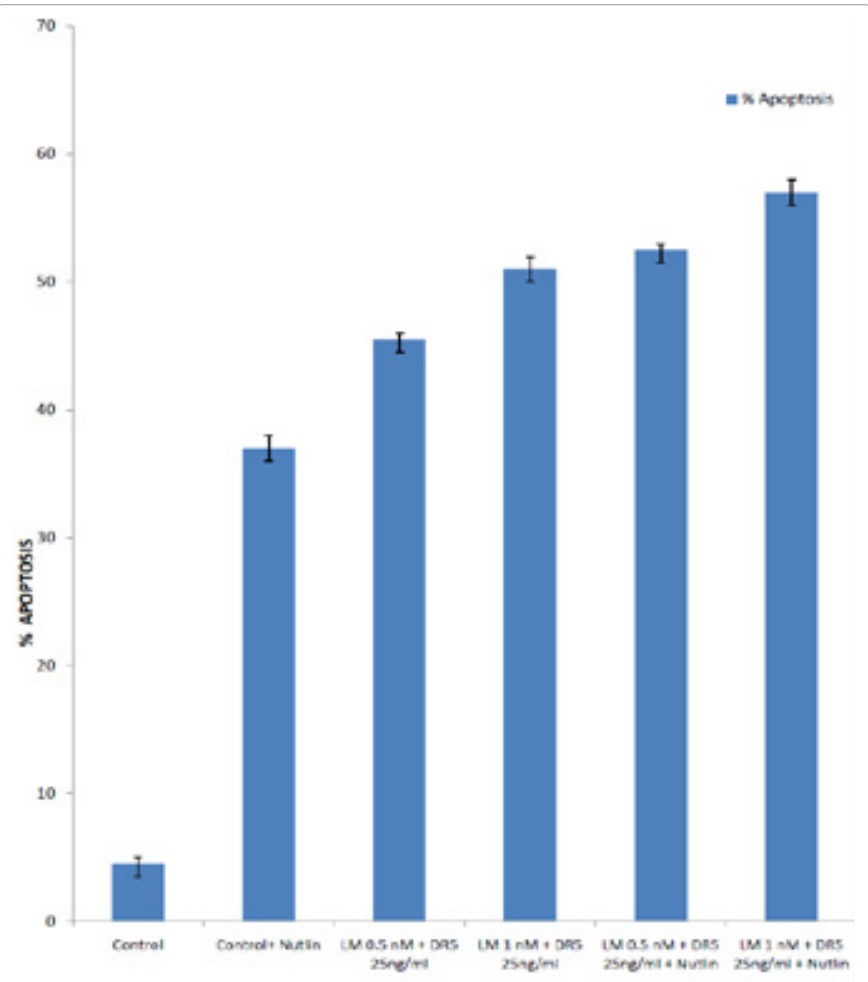

Figure 35: Effect of Nutlin on PC3 cells treated with leptomycin and DR5. This graph depicts the effect of nutlin on combination of varying concentrations of leptomycin and DR5 on PC3 cells. The PC3 cells were plated at 10,000cells $/ \mathrm{ml}$ in a 6 well plate and incubated for 24 hours. These were then treated with nutlin and incubated for 5 hours followed by addition of varying concentrations of leptomycin B, DR5 and their combinations and incubated for 24 hours. Images of cells were captured before and after incubation with drugs through light microscopy for calculating percentage apoptosis. 
mutants] treated with a combination of leptomycin B + DR5, it was found that it enhanced the percentage of apoptotic cells by $15-20 \%$. This indicates that nutlin may also have p53 independent effects. The values of percentage apoptosis that have been depicted in Tables 2 and 3 are mean values of replicate experiments. The light microscopy images of these results have been shown in Figures 30-33.

Before testing the effect of nutlin on PC3 cells already treated with leptomycin and DR5, the effects of leptomycin, DR5 and their combined effects in varying concentrations is depicted in Table 2 and as graph in Figure 34.

The effect of nutlin on PC3 cells already treated with leptomycin and DR5 and their combined effects in varying concentrations is depicted in Table 3 and Figure 35.

\section{Effect of Nutlin on LNCAP cells}

In this experiment, a 6-well plate was plated with LNCAP cells at a density of 10,000 cells $/ \mathrm{ml}$ and incubated for 24 hours. After incubation, the cells were treated with Nutlin 3 a for 5 hours followed by addition of leptomycin B, DR5 and their combination in varying concentrations in respective wells [as described in drug treatment method] and incubated for 24 hours. Images were captured under light microscope before treatment and after 24 hour incubation of treated cells to calculate the number of missing cells which in turn indicates the number of apoptotic cells, to calculate the percentage of apoptotic cells. Nutlin was added to cells treated with dual treatment [Leptomycin B + DR5] to test whether it enhances the percentage of apoptotic cells. It was observed that nutlin alone could cause $45 \%$ of the LNCAP cells to die through apoptosis. On combination of nutlin with dual treatment, it was observed that the percentage of apoptosis enhanced from $45 \%$ to $77 \%$, which means that nutlin greatly enhances the percentage of

\begin{tabular}{|l|l|}
\hline DRUG & \% Apoptosis \\
\hline Control & 4 \\
\hline LM $0.5 \mathrm{nM}$ & 15.5 \\
\hline LM $1 \mathrm{nM}$ & 23 \\
\hline DR5 $25 \mathrm{ng} / \mathrm{ml}$ & 37.5 \\
\hline LM $0.5 \mathrm{nM}+$ DR5 $25 \mathrm{ng} / \mathrm{ml}$ & 44.5 \\
\hline LM $1 \mathrm{nM}+$ DR5 $25 \mathrm{ng} / \mathrm{ml}$ & 51 \\
\hline
\end{tabular}

Table 4: Effect of leptomycin, DR5 and their combination in varying concentrations on LNCAP cells. The LNCAP cells were plated at $10,000 \mathrm{cell} / \mathrm{s} / \mathrm{ml}$ in a 6 well plate and incubated for 24 hours. These were then treated with varying concentrations of leptomycin B, DR5 and their combinations and incubated for 24 hours. Images of cells were captured before and after incubation with drugs through light microscopy for calculating percentage apoptosis.

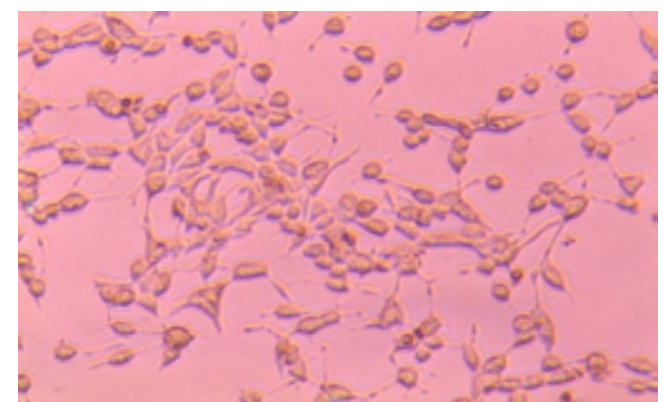

Figure 36: LNCAP cells treated with nutlin [0 hours]. This picture depicts a section of LNCAP cells at a density of 10,000 cells $/ \mathrm{ml}$ that have been treated with nutlin and have not been incubated.

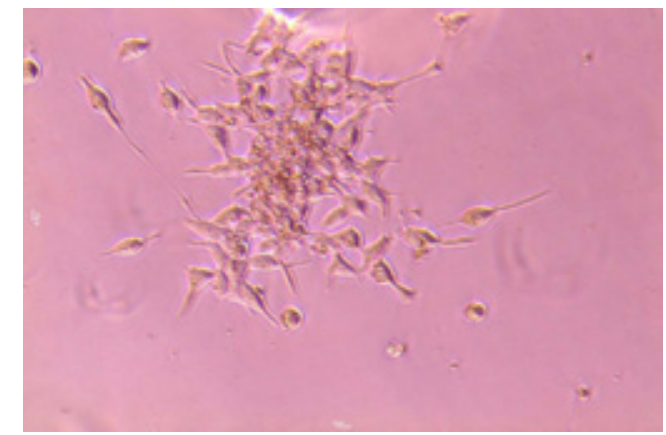

Figure 37: LNCAP cells treated with nutlin [24 hours]. This picture depicts the same section of LNCAP cells from figure 32 that have been incubated for 24 hours after treatment with nutlin. The percentage of apoptosis was found to be $44.5 \%$.

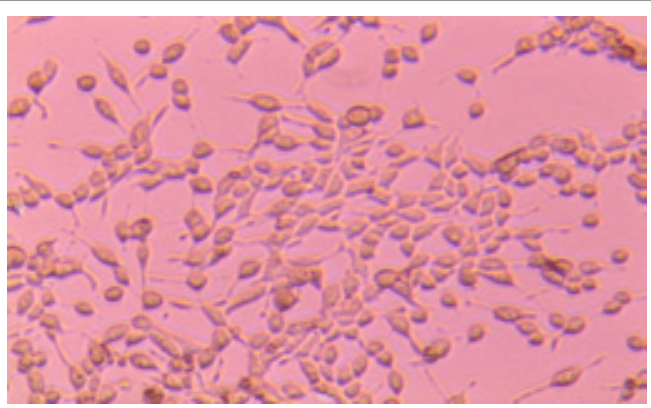

Figure 38: LNCAP cells treated with $1 \mathrm{nM}$ leptomycin+25ng/ml DR5 + nutlin [0 hours]. This picture depicts a section of LNCAP cells at a density of 10,000 cells/ $\mathrm{ml}$ that have been treated with nutlin for 5 hours followed by addition of $1 \mathrm{nM}$ leptomycin $+25 \mathrm{ng} / \mathrm{ml}$ DR5 and have not been incubated.

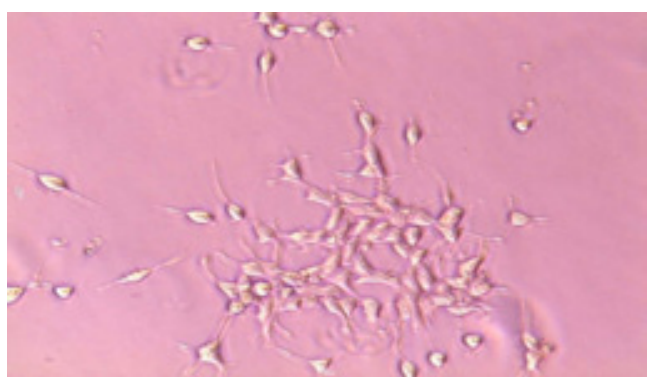

Figure 39: LNCAP cells treated with 1nM leptomycin+25ng/ml DR5 + nutlin [24 hours]. This picture depicts the same section of LNCAP cells from figure 32 that have been incubated for 24 hours after treatment with $1 \mathrm{nM}$ leptomycin $+25 \mathrm{ng} / \mathrm{ml}$ DR5+nutlin. The percentage of apoptosis was found to be $77.25 \%$.

apoptosis in LNCAP cells when combined with dual treatment. The values of percentage apoptosis that have been depicted in Tables 4 and 5 are mean values of replicate experiments. The light microscopy images of these results have been shown in Figures 36-39.

Before testing the effect of nutlin on LNCAP cells already treated with leptomycin and DR5, the effects of leptomycin, DR5 and their combined effects in varying concentrations is depicted in Table 4 and as graph in Figure 40.

The effect of nutlin on LNCAP cells treated with leptomycin and DR5 and their combined effects in varying concentrations is depicted in Table 5 and Figure 41. 


\section{Effect of Nutlin on MCF7 cells}

In this experiment, a 6-well plate was plated with MCF7 cells at a density of 10,000 cells $/ \mathrm{ml}$ and incubated for 24 hours. After incubation, the cells were treated with Nutlin 3 a for 5 hours followed by addition of leptomycin B, DR5 and their combination in varying concentrations in respective wells [as described in drug treatment method] and incubated for 24 hours. Images were captured under light microscope before treatment and after 24 hour incubation of treated cells to calculate the number of missing cells which in turn indicates the number of apoptotic cells, to calculate the percentage of apoptotic cells. Nutlin was added to cells treated with dual treatment [Leptomycin B + DR5] to test whether it enhances the percentage of apoptotic cells. It was observed that nutlin alone could cause $47.5 \%$ of the MCF7 cells to die through apoptosis. On combination of nutlin with dual treatment, it was observed that the percentage of apoptosis enhanced from $47.5 \%$

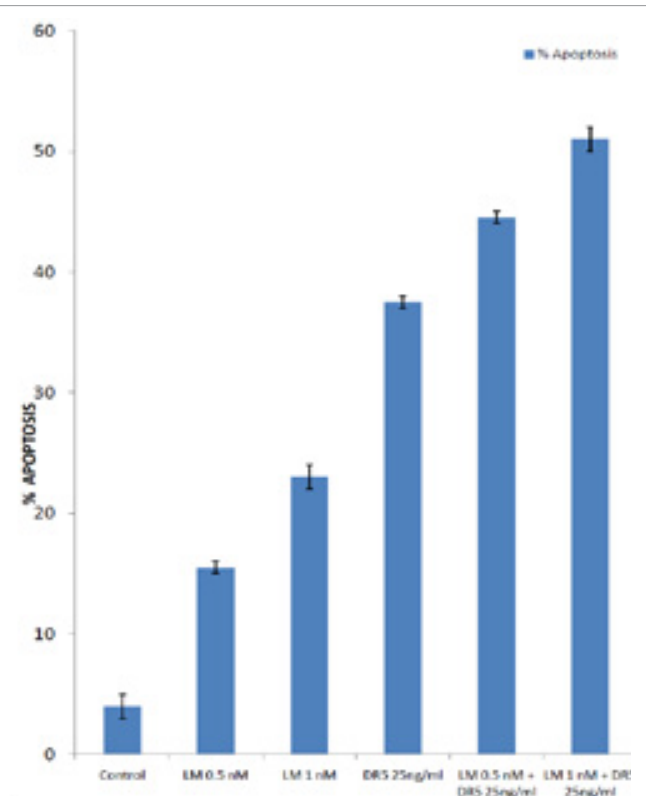

Figure 40: Effect of leptomycin and DR5 on LNCAP cells. This graph depicts effect of leptomycin, DR5 and their combination in varying concentrations on LNCAP cells. In this experiment, LNCAP cells were plated at 10,000 cells $/ \mathrm{ml}$ in a 6 well plate and incubated for 24 hours. These were then treated with varying concentrations of leptomycin B, DR5 and their combinations and incubated for 24 hours. Images of cells were captured before and after incubation with drugs through light microscopy for calculating percentage apoptosis.

\begin{tabular}{|l|l|}
\hline DRUG & \% Apoptosis \\
\hline Control & 4 \\
\hline Nutlin & 44.5 \\
\hline LM $0.5 \mathrm{nM}+$ DR5 $25 \mathrm{ng} / \mathrm{ml}$ & 44.5 \\
\hline LM $1 \mathrm{nM}+$ DR5 $25 \mathrm{ng} / \mathrm{ml}$ & 51 \\
\hline LM $0.5 \mathrm{nM}+$ DR5 $25 \mathrm{ng} / \mathrm{ml}+$ Nutlin & 72.9 \\
\hline LM $1 \mathrm{nM}+$ DR5 $25 \mathrm{ng} / \mathrm{ml}+$ Nutlin & 77.25 \\
\hline
\end{tabular}

Table 5: Effect of nutlin on combination of varying concentrations of leptomycin and DR5 on LNCAP cells- The LNCAP cells were plated at 10,000 cells $/ \mathrm{ml}$ in a 6 well plate and incubated for 24 hours. These were then treated with nutlin and incubated for 5 hours followed by addition of varying concentrations of leptomycin B, DR5 and their combinations and incubated for 24 hours. Images of cells were captured before and after incubation with drugs through light microscopy for calculating percentage apoptosis.

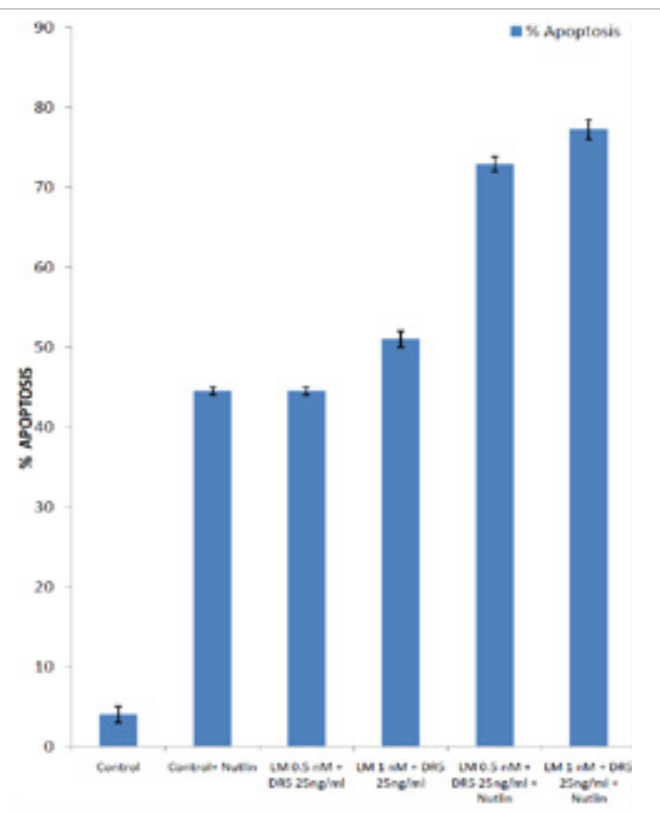

Figure 41: Effect of Nutlin on LNCAP cells treated with leptomycin and DR5. This graph depicts the effect of nutlin on combination of varying concentrations of leptomycin and DR5 on LNCAP cells. The LNCAP cells were plated at $10,000 \mathrm{cells} / \mathrm{ml}$ in a 6 well plate and incubated for 24 hours. These were then treated with nutlin and incubated for 5 hours followed by addition of varying concentrations of leptomycin B, DR5 and their combinations and incubated for 24 hours. Images of cells were captured before and after incubation with drugs through light microscopy for calculating percentage apoptosis.

\begin{tabular}{|l|l|}
\hline DRUG & \% Apoptosis \\
\hline Control & 1.5 \\
\hline LM $0.5 \mathrm{nM}$ & 10.92 \\
\hline LM $1 \mathrm{nM}$ & 25.27 \\
\hline DR5 $25 \mathrm{ng} / \mathrm{ml}$ & 34 \\
\hline LM $0.5 \mathrm{nM}+$ DR5 $25 \mathrm{ng} / \mathrm{ml}$ & 41.13 \\
\hline LM $1 \mathrm{nM}+$ DR5 $25 \mathrm{ng} / \mathrm{ml}$ & 46.285 \\
\hline
\end{tabular}

Table 6: Effect of leptomycin, DR5 and their combination in varying concentrations on MCF7 cells. The MCF7 cells were plated at $10,000 \mathrm{cells} / \mathrm{ml}$ in a 6 well plate and incubated for 24 hours. These were then treated with varying concentrations of leptomycin B, DR5 and their combinations and incubated for 24 hours. Images of cells were captured before and after incubation with drugs through light microscopy for calculating percentage apoptosis.

to $78 \%$, which means that nutlin enhances the percentage of apoptosis in MCF7 cells when combined with dual treatment. The values of percentage apoptosis that have been depicted in Tables 6 and 7 are mean values of replicate experiments. The light microscopy images of these results have been shown in Figures 42-45.

Before testing the effect of nutlin on MCF7 cells treated with leptomycin and DR5, the effects of leptomycin, DR5 and their combined effects in varying concentrations is depicted in Table 6 and Figure 46.

The effect of nutlin on MCF7 cells treated with leptomycin and DR5 and their combined effects in varying concentrations are depicted in Table 7 and Figure 47.

Statistical comparison of effects of dual treatment and Nutlin in PC3, LNCAP and MCF7 Cells

The comparison between the effects of varying concentrations of 
leptomycin, DR5 and their combination with nutlin on PC3, LNCAP and MCF7 cells can be obtained by performing two-way ANOVA using the values shown in Table 8 .

Using "Stats direct" statistical software tool, two-way ANOVA was performed using values from Table 8 and the following results were obtained:

Treatments=PC3, LNCAP and MCF7.

$\mathrm{F}(\mathrm{VR}$ between blocks $)=47.992462 ; \mathrm{P}<0.0001$

$\mathrm{F}(\mathrm{VR}$ between treatments $)=2.067256 ; \mathrm{P}=0.1634$

With help of Tukey multiple comparison, results between PC3, LNCAP and MCF7 cells were compared:

\begin{tabular}{|l|l|}
\hline DRUG & \% Apoptosis \\
\hline Control & 1.5 \\
\hline Nutlin & 47.5 \\
\hline LM $0.5 \mathrm{nM}+$ DR5 $25 \mathrm{ng} / \mathrm{ml}$ & 41.13 \\
\hline LM $1 \mathrm{nM}+$ DR5 $25 \mathrm{ng} / \mathrm{ml}$ & 46.285 \\
\hline LM $0.5 \mathrm{nM}+$ DR5 $25 \mathrm{ng} / \mathrm{ml}+$ Nutlin & 75.77 \\
\hline LM $1 \mathrm{nM}+$ DR5 $25 \mathrm{ng} / \mathrm{ml}+$ Nutlin & 78.63 \\
\hline
\end{tabular}

Table 7: Effect of nutlin on combination of varying concentrations of leptomycin and DR5 on MCF7 cells- MCF7 cells were plated at $10,000 \mathrm{cells} / \mathrm{ml}$ in a 6 well plate and incubated for 24 hours. These were then treated with nutlin and incubated for 5 hours followed by addition of varying concentrations of leptomycin B, DR5 and their combinations and incubated for 24 hours. Images of cells were captured before and after incubation with drugs through light microscopy for calculating percentage apoptosis.

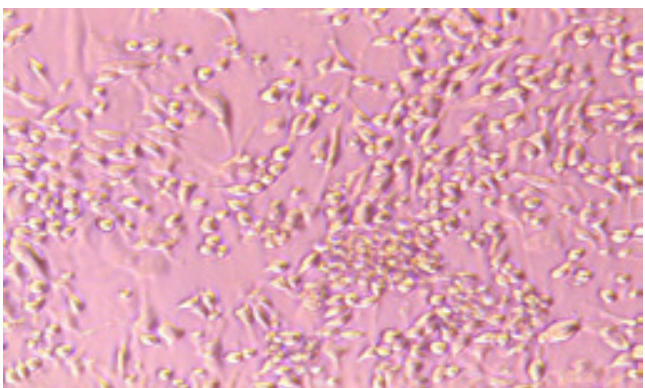

Figure 42: MCF7 cells treated with nutlin [0 hours]. This picture depicts a section of MCF7 cells at a density of 10,000 cells $/ \mathrm{ml}$ that have been treated with nutlin and have not been incubated.

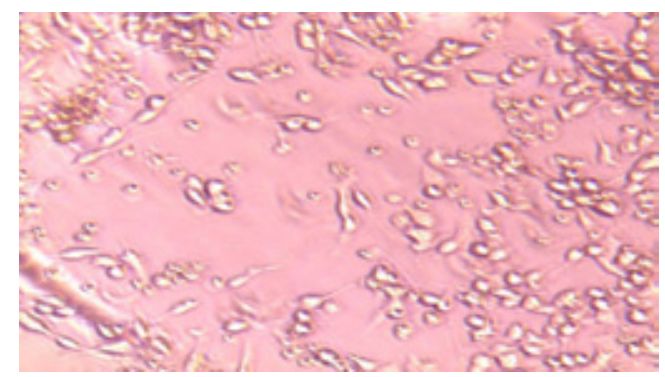

Figure 43: MCF7 cells treated with nutlin [24 hours]. This picture depicts the same section of MCF7 cells from figure 32 that have been incubated for 24 hours after treatment with nutlin. The percentage of apoptosis was found to be $47.5 \%$.

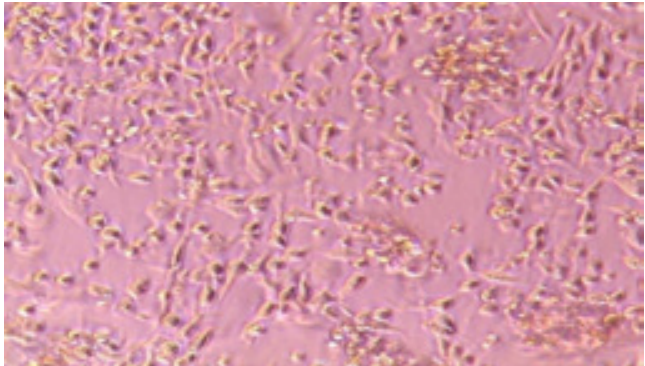

Figure 44: MCF7 cells treated with $1 \mathrm{nM}$ leptomycin $+25 \mathrm{ng} / \mathrm{ml} \mathrm{DR5}+$ nutlin [0 hours]. This picture depicts a section of MCF7 cells at a density of 10,000 cells/ $\mathrm{ml}$ that have been treated with nutlin for 5 hours followed by addition of $1 \mathrm{nM}$ leptomycin+ $25 \mathrm{ng} / \mathrm{ml} \mathrm{DR5}$ and have not been incubated.

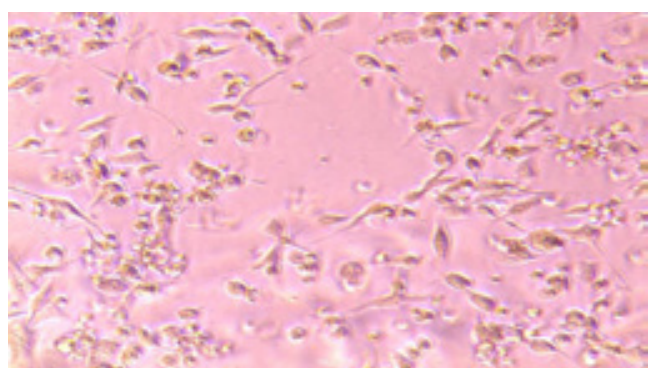

Figure 45: MCF7 cells treated with $1 \mathrm{nM}$ leptomycin $+25 \mathrm{ng} / \mathrm{ml} \mathrm{DR5}+$ nutlin [24 hours]. This picture depicts the same section of MCF7 cells from figure 32 that have been incubated for 24 hours after treatment with $1 \mathrm{nM}$ leptomycin $+25 \mathrm{ng} / \mathrm{ml}$ DR5+nutlin. The percentage of apoptosis was found to be $78.63 \%$.

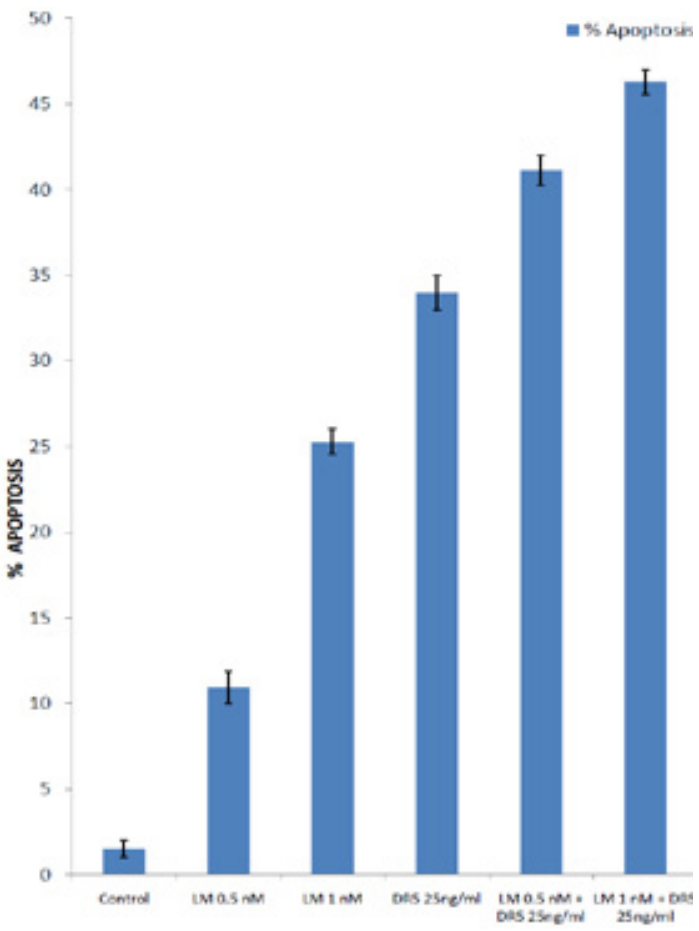

Figure 46: Effect of leptomycin and DR5 on MCF7 cells. This graph depicts the effect of leptomycin, DR5 and their combination in varying concentrations on MCF7 cells. In this experiment, MCF7 cells were plated at 10,000 cells $/ \mathrm{ml}$ in a 6 well plate and incubated for 24 hours. These were then treated with varying concentrations of leptomycin B, DR5 and their combinations and incubated for 24 hours. Images of cells were captured before and after incubation with drugs through light microscopy for calculating percentage apoptosis. 


\begin{tabular}{|c|c|c|c|}
\hline Comparison & Mean difference $\mathrm{L}(95 \% \mathrm{Cl})$ & & |L/SE(L)| \\
\hline PC3 vs. LNCAP & $-5.95625(-13.62976$ to 1.71726$)$ & 2.766895 & $P=0.148$ \\
\hline PC3 vs. MCF7 & $\begin{array}{lll}-4.438125 & (-12.111635 \\
2.061671 & \end{array}$ & $3.235385)$ & $P=0.3308$ \\
\hline $\begin{array}{l}\text { LNCAP } \\
\text { MCF7 }\end{array}$ & 1.518125 (-6.155385 to 9.1916 & 0.705 & $+P=0.872$ \\
\hline
\end{tabular}

Based on results of Two-way ANOVA tests obtained through Stats direct tool, it can be observed that $\mathrm{p}$-value $<0.05$ in case of varying concentrations and combinations of LMB and DR5, which means that there is significant difference between the different treatments. In case of the effect of different treatments on PC3, LNCAP and MCF 7 cells, the $\mathrm{p}$-value $=0.1634$, which means that there is no significant difference between the percentage of apoptotic cells in PC3, LNCAP and MCF 7 cells. In case of comparison of effect of treatments in PC3 vs. LNCAP,

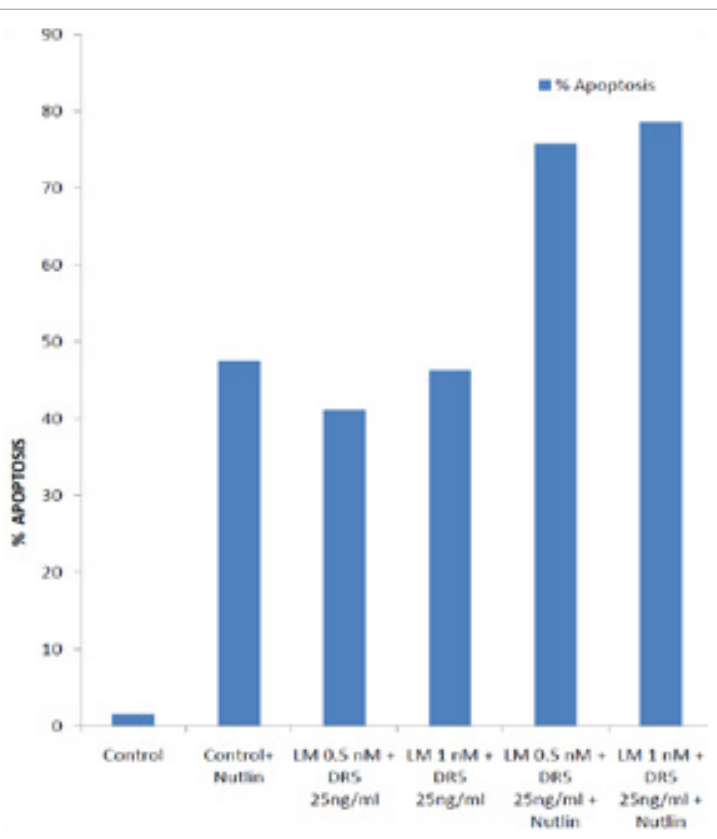

Figure 47: Effect of Nutlin on MCF7 cells treated with leptomycin and DR5. This graph depicts the effect of nutlin on combination of varying concentrations of leptomycin and DR5 on MCF7 cells. MCF7 cells were plated at 10,000cells/ $\mathrm{ml}$ in a 6 well plate and incubated for 24 hours. These were then treated with nutlin and incubated for 5 hours followed by addition of varying concentrations of leptomycin B, DR5 and their combinations and incubated for 24 hours. Images of cells were captured before and after incubation with drugs through light microscopy for calculating percentage apoptosis.

\begin{tabular}{|l|l|l|l|}
\hline TREATMENT & PC3 & LNCAP & MCF7 \\
\hline Control & 4.5 & 4 & 1.5 \\
\hline Nutlin & 37 & 44.5 & 47.5 \\
\hline LM $0.5 \mathrm{nM}$ & 12 & 15.5 & 10.92 \\
\hline LM $1 \mathrm{nM}$ & 22 & 23 & 25.27 \\
\hline DR5 $25 \mathrm{ng} / \mathrm{ml}$ & 33.5 & 37.5 & 34 \\
\hline LM $0.5 \mathrm{nM}+$ DR5 $25 \mathrm{ng} / \mathrm{ml}$ & 45.5 & 44.5 & 41.13 \\
\hline LM $1 \mathrm{nM}+$ DR5 $25 \mathrm{ng} / \mathrm{ml}$ & 51 & 51 & 46.285 \\
\hline LM $0.5 \mathrm{nM}+$ DR5 $25 \mathrm{ng} / \mathrm{ml}+$ Nutlin & 52.5 & 72.9 & 75.77 \\
\hline LM $1 \mathrm{nM}+$ DR5 $25 \mathrm{ng} / \mathrm{ml}+$ Nutlin & 57 & 77.25 & 78.63 \\
\hline
\end{tabular}

Table 8: Table comparing the effects of varying concentrations of leptomycin, DR5 and their combination with nutlin on PC3, LNCAP and MCF7 cells by using \% apoptosis values.
PC3 vs. MCF7 and LNCAP vs. MCF7, the p-values have been obtained as $0.148,0.3308$ and 0.8727 respectively, which shows that there is no difference in the treatments of LNCAP vs. MCF7, PC3 vs. MCF7 and PC3 vs. LNCAP.

On performing two way ANOVA using \% apoptosis values between leptomycin alone, DR5 alone and dual treatment in PC3, MCF7 and LNCAP cells, the following data was obtained:

\section{$\mathrm{F}($ VR between blocks $)=321.907603 ; \mathrm{P}<0.0001$}

\section{$\mathrm{F}(\mathrm{VR}$ between treatments $)=4.645312 ; \mathrm{P}=0.0906$}

In case of results of Two-way ANOVA tests obtained through Stats direct tool, it can be observed that $\mathrm{p}$-value $<0.05[\mathrm{P}<0.0001]$ in case of LMB alone, DR5 alone and dual treatment, which infers that there is statistical difference between single treatments and dual treatment. But in case of comparison between the treatments on PC3, MCF7 and LNCAP cells, it has been observed that p-value is greater than 0.05 , which means that there is no significant difference between the different treatments on these cells.

On performing two way ANOVA using \% apoptosis values between nutlin alone treatment and LM $0.5 \mathrm{nM}+$ DR5 $25 \mathrm{ng} / \mathrm{ml}+$ Nutlin in PC3, LNCAP and MCF7 cells, the p-values have obtained as follows:

$\mathrm{F}(\mathrm{VR}$ between blocks $)=31.614641 ; \mathrm{P}=0.0302$

$\mathrm{F}(\mathrm{VR}$ between treatments $)=5.928015 ; \mathrm{P}=0.1443$

In case of results of Two-way ANOVA tests obtained through Stats direct tool, it can be observed that p-value $<0.05$ in case of Nutlin alone treatment and LM $0.5 \mathrm{nM}+$ DR5 $25 \mathrm{ng} / \mathrm{ml}+$ Nutlin, which means that there is difference in treatments. This indicates that nutlin enhances the $\%$ apoptosis when included in dual treatment. In case of comparison of treatments between PC3, LNCAP and MCF7, p-value is greater than 0.05 , which means that there is no statistical difference.

\section{Effect of Leptomycin on gene expression of PC3 Cells}

PC3 cells were cultured in a 6 well plate at 50,000 cells $/ \mathrm{ml}$ and treated with $1 \mathrm{nM}$ and $5 \mathrm{nM}$ concentrations of Leptomycin B. The plate was then incubated for 24 hours. RNA from these cells was isolated and these RNA samples were then subjected to reverse transcription to obtain cDNA of the genes being expressed. These cDNA samples were then subjected to RT-PCR using Taqman probing to check the levels of expression of a specific set of genes namely HPRT, BIRC3, DR4, BIRC4, DR5, DCR1, DCR2 and c-FLIP using a specific set of primers. The analysis of levels of relative gene expression on treatment with 1 $\mathrm{nM}$ and $5 \mathrm{nM}$ leptomycin $\mathrm{B}$ has shown that:

BIRC3, BIRC4, DR5, DCR1, DCR2, c-FLIP=relatively upregulated

DR4=relatively downregulated.

From the above results, on comparing with the reference gene [HPRT], it is seen that: (a) BIRC3 has been upregulated although it codes for cIAP, an inhibitor of apoptosis; (b) BIRC4 has been upregulated as it codes for an anti apoptotic protein XIAP; (c) DR4 has been downregulated and DR5 has been found to be relatively upregulated and these are expressed for TNF ligand to bind; (d) DCR 1 and DCR 2 have been found to be highly upregulated although they inhibit apoptosis by binding to TNF ligands/TRAIL; (e) c-FLIP levels have been upregulated although it is also an anti apoptotic protein.

When PC3 cells were treated with varying concentrations of leptomycin, the change in gene expression with respect to the control 


\begin{tabular}{|c|c|c|c|c|c|c|c|}
\hline Target gene & $\mathrm{C}_{\mathrm{t}}$ value [control] & $\mathrm{C}_{\mathrm{t}}$ value [treated] & $\Delta \mathrm{C}_{\mathrm{t}}$ value [control] & $\Delta \mathrm{C}_{\mathrm{t}}$ value [treated] & $\Delta \Delta C_{t}$ value & $2^{-\Delta \Delta C t}$ value & Gene expression \\
\hline HPRT [reference] & 31.465 & 30.967 & - & - & 0 & 1 & - \\
\hline BIRC 3 & 31.482 & 29.084 & 0.017 & 0.883 & 0.866 & 0.548 & 1.8 fold decrease \\
\hline BIRC 4 & 31.514 & 31.213 & 0.049 & 0.246 & 0.197 & 0.872 & 1.2 fold decrease \\
\hline DR4 & 29.286 & 28.408 & -2.179 & -2.559 & -0.38 & 1.301 & 1.3 fold increase \\
\hline DR5 & 33.52 & 31.695 & 2.055 & 0.728 & -1.327 & 2.508 & 2.5 fold increase \\
\hline DCR 1 & 34.432 & 32.643 & 2.967 & 1.676 & -1.291 & 2.446 & 2.5 fold increase \\
\hline DCR 2 & 31.274 & 29.195 & -0.191 & -1.772 & -1.581 & 2.99 & $\sim 3$ fold increase \\
\hline c-FLIP & 29.363 & 28.632 & -2.102 & -2.335 & -0.233 & 1.175 & $\sim 1.2$ fold increase \\
\hline
\end{tabular}

Table 9: Effect on $1 \mathrm{nM}$ leptomycin on the change in gene expression of a specific set of genes related to apoptosis in PC3 cells using $\mathrm{C}_{\mathrm{t}}$ values obtained by RT-PCR.

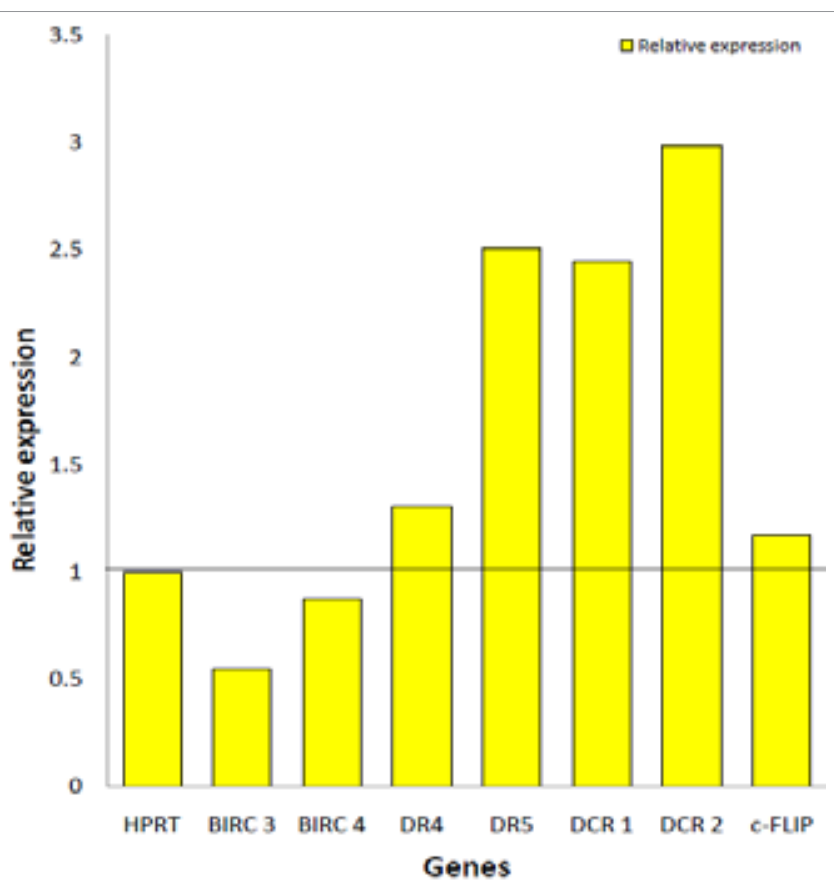

Figure 48: Graph showing the effect of $1 \mathrm{nM} \mathrm{B}$ leptomycin on the change in gene expression of a specific set of genes related to apoptosis in PC3 cells using $2^{-\Delta \Lambda C t}$ values.

sample was obtained through calculation of $2^{-\Delta \Delta \mathrm{Ct}}$ from threshold values $\left[\mathrm{C}_{\mathrm{t}}\right]$ obtained through RT-PCR. The calculation of change in gene expression on treatment with $1 \mathrm{nM}$ leptomycin has been explained in Table 9 and Figure 48 as follows:

The calculation of change in gene expression in PC3 cells on treatment with $5 \mathrm{nM}$ leptomycin has been explained in Table 10 and Figure 49 as follows:

\section{Effect of Leptomycin on gene expression of LNCAP Cells}

LNCAP cells were cultured in a 6 well plate at 50,000 cells/ml and treated with $1 \mathrm{nM}$ and $5 \mathrm{nM}$ concentrations of Leptomycin B. The plate was then incubated for 24 hours. RNA from these cells was isolated and these RNA samples were then subjected to reverse transcription to obtain cDNA of the genes being expressed. These cDNA samples were then subjected to RT-PCR using Taqman probing to check the levels of expression of a specific set of genes namely HPRT, BIRC3, DR4, BIRC4, DR5, DCR1, DCR2 and c-FLIP using a specific set of primers. The analysis of levels of relative gene expression on treatment with $1 \mathrm{nM}$ and $5 \mathrm{nM}$ leptomycin B has shown that: BIRC3, DR5, DCR1, DCR2 are relatively upregulated; DR4, BIRC4, c-FLIP are relatively downregulated.

From the above results, on comparing with the reference gene [HPRT], it is seen that: (a) BIRC3 has been upregulated although it codes for cIAP, an inhibitor of apoptosis; (b) BIRC4 has been downregulated and it codes for an anti apoptotic protein XIAP; (c) DR4 has been downregulated and DR5 are relatively upregulated and these are expressed for TNF ligand to bind; (d) DCR 1 and DCR 2 are relatively upregulated although they inhibit apoptosis by binding to TNF ligands/TRAIL; (e) c-FLIP levels are downregulated and it is also an anti apoptotic protein.

When LNCAP cells were treated with varying concentrations of leptomycin, the change in gene expression with respect to the control sample was obtained through calculation of $2^{-\Delta \Delta C t}$ from threshold values $\left[\mathrm{C}_{\mathrm{t}}\right]$ obtained through RT-PCR. The calculation of change in gene expression on treatment with $1 \mathrm{nM}$ leptomycin has been explained in Table 11 and Figure 50 as follows:

The calculation of change in gene expression in LNCAP cells on treatment with $5 \mathrm{nM}$ leptomycin has been explained in Table 12 and Figure 51 as follows: 


\begin{tabular}{|c|c|c|c|c|c|c|c|}
\hline Target gene & $\mathrm{C}_{\mathrm{t}}$ value [control] & $\mathrm{C}_{\mathrm{t}}$ value [treated] & $\begin{array}{l}\Delta \mathrm{C}_{\mathrm{t}} \text { value } \\
\text { [control] }\end{array}$ & $\begin{array}{l}\Delta \mathrm{C}_{\mathrm{t}} \text { value } \\
\text { [treated] }\end{array}$ & $\Delta \Delta C_{t}$ value & $2^{-\Delta \Delta C t}$ value & Gene expression \\
\hline HPRT [reference] & 31.209 & 31.479 & 0 & 0 & 0 & 1 & 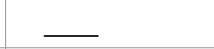 \\
\hline BIRC 3 & 31.823 & 30.282 & 0.614 & -1.197 & -1.811 & 3.508 & 3.5 fold increase \\
\hline BIRC 4 & 31.012 & 29.472 & -0.197 & -2.007 & -1.81 & 3.506 & 3.5 fold increase \\
\hline DR4 & 29.292 & 30.012 & -1.917 & -1.467 & 0.45 & 0.732 & 1.36 fold decrease \\
\hline DR5 & 33.202 & 31.014 & 1.993 & -0.465 & -2.458 & 5.494 & $\sim 5.5$ fold decrease \\
\hline DCR 1 & 34.629 & 30.362 & 3.42 & -1.117 & -4.537 & 23.215 & 23 fold increase \\
\hline DCR 2 & 31.013 & 28.254 & -0.196 & -3.225 & -3.029 & 8.162 & 8 fold increase \\
\hline c-FLIP & 29.328 & 26.029 & -1.881 & -5.45 & -3.569 & 11.867 & $\sim 12$ fold increase \\
\hline
\end{tabular}

Table 10: Effect on 5nM leptomycin on the change in gene expression of a specific set of genes related to apoptosis in PC3 cells using $\mathrm{C}_{\mathrm{t}}$ values obtained by RT-PCR.

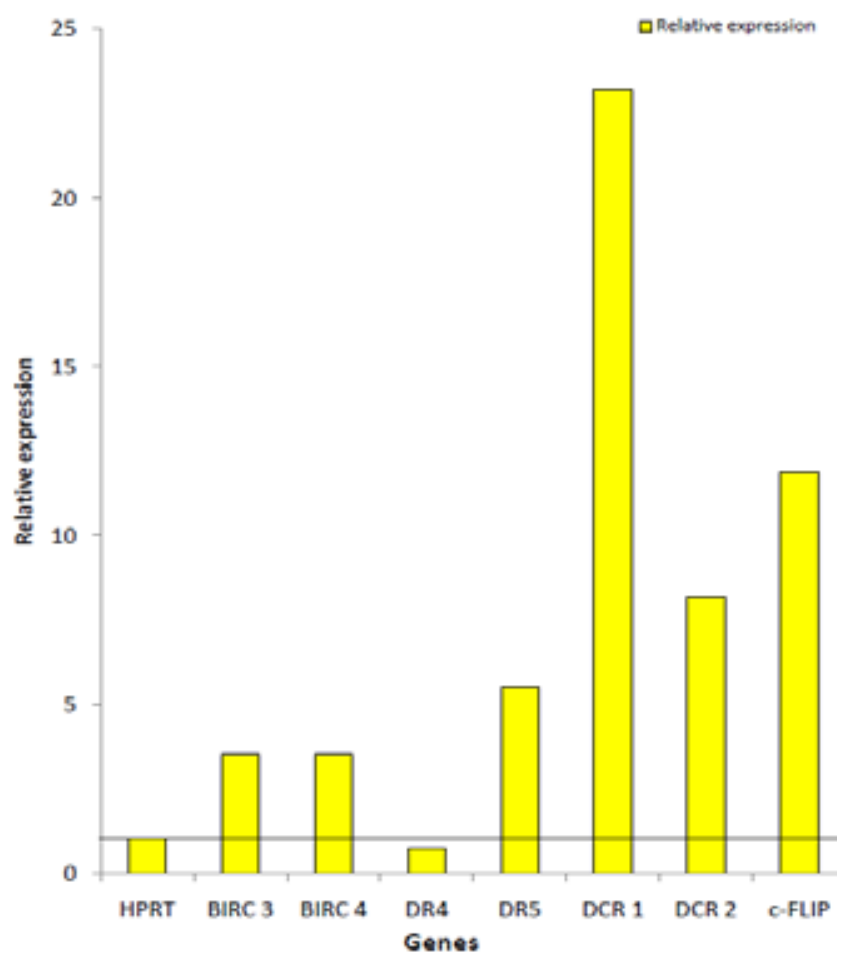

Figure 49: Graph showing the effect on $5 \mathrm{nM}$ leptomycin B on the change in gene expression of a specific set of genes related to apoptosis in PC3 cells using $2^{-\Delta \Delta C t}$ values.

\section{Effect of Leptomycin on gene expression of MCF7 Cells}

LNCAP cells were cultured in a 6 well plate at 50,000 cells $/ \mathrm{ml}$ and treated with $1 \mathrm{nM}$ and $5 \mathrm{nM}$ concentrations of Leptomycin B. The plate was then incubated for 24 hours. RNA from these cells was isolated and these RNA samples were then subjected to reverse transcription to obtain cDNA of the genes being expressed. These cDNA samples were then subjected to RT-PCR using Taqman probing to check the levels of expression of a specific set of genes namely HPRT, BIRC3, DR4, BIRC4, DR5, DCR1, DCR2 and c-FLIP using a specific set of primers. The analysis of levels of relative gene expression on treatment with $1 \mathrm{nM}$ and $5 \mathrm{nM}$ leptomycin $\mathrm{B}$ has shown that: BIRC3, DR5, DCR1, c-FLIP are relatively upregulated; DR4, BIRC4, DCR2 are relatively downregulated.

From the above results, on comparing with the reference gene [HPRT], it is seen that: (a) BIRC3 has been upregulated although it codes for cIAP, an inhibitor of apoptosis; (b) BIRC4 has been downregulated and it codes for an anti apoptotic protein XIAP; (c) DR4 has been downregulated and DR5 are relatively upregulated and these are expressed for TNF ligand to bind; (d) DCR 1 is downregulated and DCR 2 is upregulated and they inhibit apoptosis by binding to TNF ligands/TRAIL; (e) c-FLIP levels are upregulated although it is an anti apoptotic protein.

When MCF 7 cells were treated with varying concentrations of leptomycin, the change in gene expression with respect to the control sample was obtained through calculation of $2^{-\Delta \Delta \mathrm{Ct}}$ from threshold values $\left[\mathrm{C}_{\mathrm{t}}\right]$ obtained through RT-PCR. The calculation of change in gene expression on treatment with $1 \mathrm{nM}$ leptomycin has been explained in Table 13 and Figure 52 as follows:

The calculation of change in gene expression in LNCAP cells on 


\begin{tabular}{|c|c|c|c|c|c|c|c|}
\hline Target gene & $\mathrm{C}_{\mathrm{t}}$ value [control] & $\mathrm{C}_{\mathrm{t}}$ value [treated] & $\begin{array}{l}\Delta \mathrm{C}_{\mathrm{t}} \text { value } \\
\text { [control] }\end{array}$ & $\Delta \mathrm{C}_{\mathrm{t}}$ value [treated] & $\Delta \Delta \mathrm{C}_{\mathrm{t}}$ value & $2^{-\Delta \Delta C t}$ value & Gene expression \\
\hline HPRT [reference] & 30.74 & 31.302 & 0 & 0 & 0 & 1 & 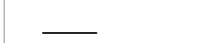 \\
\hline BIRC 3 & 31.682 & 31.53 & 0.942 & 0.228 & -0.714 & 1.64 & 1.6 fold increase \\
\hline BIRC 4 & 31.133 & 32.126 & 0.393 & 0.824 & 0.431 & 0.741 & 1.35 fold decrease \\
\hline DR4 & 33.361 & 32.537 & 2.621 & 1.235 & -1.386 & 2.613 & 2.6 fold increase \\
\hline DR5 & 31.382 & 29.72 & 0.642 & -1.582 & -2.224 & 4.671 & 4.6 fold increase \\
\hline DCR 1 & 30.529 & 30.271 & -0.211 & -1.031 & -0.82 & 1.765 & 1.76 fold increase \\
\hline DCR 2 & 31.212 & 30.528 & 0.472 & -0.774 & -1.246 & 2.371 & 2.3 fold increase \\
\hline c-FLIP & 31.293 & 32.338 & 0.553 & 1.036 & 0.483 & 0.715 & 1.4 fold decrease \\
\hline
\end{tabular}

Table 11: Effect of $1 \mathrm{nM}$ leptomycin on the change in gene expression of a specific set of genes related to apoptosis in LNCAP cells using $\mathrm{C}_{t}$ values obtained by RT-PCR.

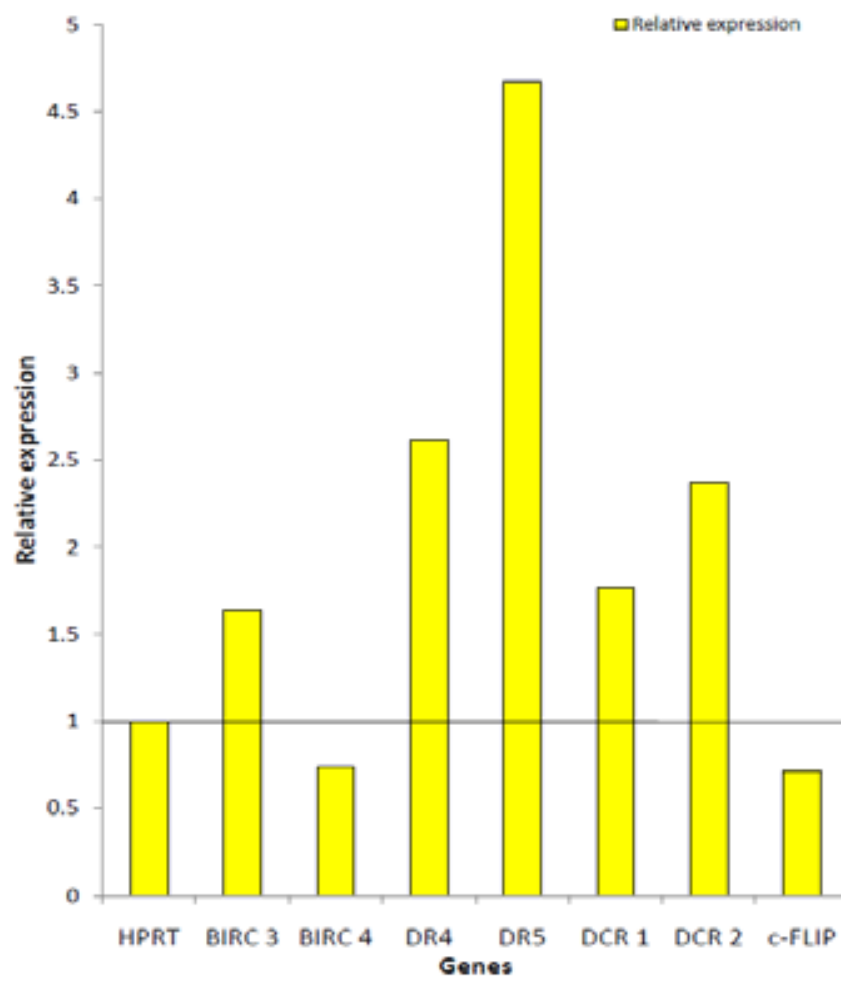

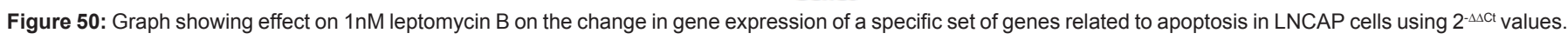

treatment with $5 \mathrm{nM}$ leptomycin has been explained in Table 14 and Figure 53 as follows:

\section{Discussion}

\section{Effect of Leptomycin B [LMB]}

In the previous experiments that have been conducted by [53] on anti cancer effects of leptomycin B, it was stated that cell lines that p53 wild type are less sensitive when compared to p53 mutant or null p53 cell lines. In this project, a set of experiments have been performed to test the hypothesis that leptomycin B [LMB] induces p53 induced apoptosis. This means that the null mutants of p53 do not respond to leptomycin B whereas wild type p53 cells should be affected by leptomycin B.

Leptomycin B blocks CRM1 [nuclear export protein], which causes p53 to remain in the nucleus and induce apoptosis. PC3 cells are p53 null mutants which do not possess p53. Based on the results obtained on treatment of PC3 cells with varying concentrations of leptomycin [0.5 nM, $1 \mathrm{nM}$ and $5 \mathrm{nM}$ ], the percentage of apoptotic cells has varied from 12 to $36 \%$. This indicates that the pathway through which leptomycin B induces apoptosis is p53 independent. In case of MCF7 and LNCAP cells which are p53 wild type, the percentage of apoptotic cells [17-40\%] have been similar to the results obtained in case of PC3 cells on treatment with $1 \mathrm{nM}$ and $5 \mathrm{nM}$ concentrations of leptomycin $\mathrm{B}$.

\section{Effects of dual treatment}

In case of dual treatment [leptomycin B + DR5] on PC3 cells, the concentration of LMB $5 \mathrm{nM}+$ DR5 $50 \mathrm{ng} / \mathrm{ml}$ has shown an increase of $30 \%$ to $81.33 \%$ when compared to $50.67 \%$ apoptosis caused by 50 $\mathrm{ng} / \mathrm{ml}$ DR5 alone. This increase has been observed in all cases of dual treatment on PC3 cells. This clearly indicates that leptomycin B shows p53 independent effects. For the same concentration of dual treatment on LNCAP and MCF 7 cells, a drastic increase in the percentage of apoptosis has been observed. Does this mean that leptomycin B induces 


\begin{tabular}{|c|c|c|c|c|c|c|c|}
\hline Target gene & $\mathrm{C}_{\mathrm{t}}$ value [control] & $\begin{array}{l}\mathrm{C}_{\mathrm{t}} \text { value } \\
\text { [treated] }\end{array}$ & $\Delta \mathrm{C}_{\mathrm{t}}$ value [control] & $\begin{array}{l}\Delta \mathrm{C}_{\mathrm{t}} \text { value } \\
\text { [treated] }\end{array}$ & $\Delta \Delta C_{t}$ value & $2^{-\Delta \Delta C t}$ value & Gene expression \\
\hline HPRT [reference] & 30.673 & 31.327 & 0 & 0 & 0 & 1 & 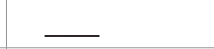 \\
\hline BIRC 3 & 31.489 & 31.289 & 0.816 & -0.038 & -0.854 & 1.807 & 1.8 fold increase \\
\hline BIRC 4 & 31.327 & 32.009 & 0.654 & 0.682 & 0.028 & 0.98 & $\begin{array}{l}\text { no change in } \\
\text { expression }\end{array}$ \\
\hline DR4 & 33.292 & 32.528 & 2.619 & 1.201 & 1.418 & 0.374 & 2.7 fold decrease \\
\hline DR5 & 31.213 & 29.289 & 0.54 & -2.038 & -2.578 & 5.971 & $\sim 6$ fold increase \\
\hline DCR 1 & 30.364 & 30.131 & -0.309 & -1.196 & -0.887 & 1.849 & 1.8 fold increase \\
\hline DCR 2 & 31.098 & 30.532 & 0.425 & -0.795 & -1.22 & 2.329 & 2.3 fold increase \\
\hline c-FLIP & 31.523 & 32.231 & 0.857 & 0.904 & 0.047 & 0.967 & $\begin{array}{l}\text { no change in } \\
\text { expression }\end{array}$ \\
\hline
\end{tabular}

Table 12: Effect of $5 \mathrm{nM}$ leptomycin on the change in gene expression of a specific set of genes related to apoptosis in LNCAP cells using $\mathrm{C}_{t}$ values obtained by RT-PCR.

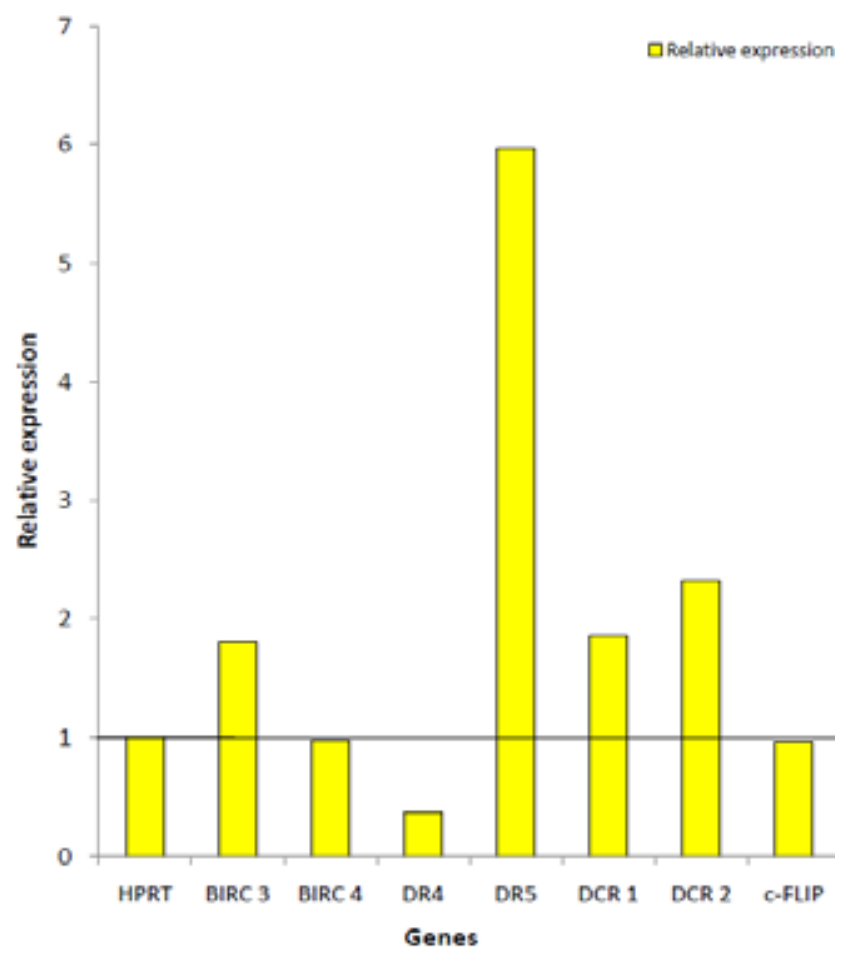

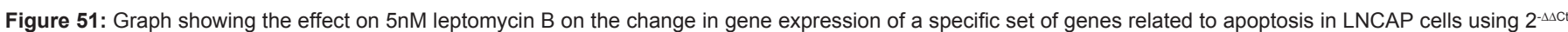
values.

p53 dependent and p53 independent apoptosis? Further research has to be continued on the molecular mechanism of effects leptomycin B and dual treatment so that the next step towards the cure for different type of cancers can be reached.

\section{Effects of Nutlin 3a on dual treatment}

Nutlin is a MDM2 antagonist that binds to MDM2 and leads to release of p53 which induces apoptosis. When nutlin alone as added to PC3 cells, it showed $37 \%$ apoptosis, which is not expected as PC3 cells are p53 null mutants. This indicates that nutlin could act through a different pathway to induce apoptosis. When nutlin was added along with lower concentrations of leptomycin and DR5 in PC3 cells, it enhanced the $\%$ apoptosis by $15-20 \%$. In case of LNCAP and MCF7 cells, when nutlin alone and dual treatment + nutlin was tested, they showed a greater amount of percentage of apoptosis [ 80\%] when compared to PC3 cells. This indicates that Nutlin has targets in the cell other than MDM2 which causes it to enhance apoptosis in PC3 cells which are p53 null mutants. Further research has to be carried out in case of molecular effects of nutlin to find out the targets that it acts on to induce apoptosis in p53 independent cells.

\section{Statistical analysis}

Based on the two-way ANOVA results obtained from the different treatments on PC3, LNCAP and MCF 7, the p-values have shown that there is no difference between the effect of treatments on the 3 different cell lines and the \% apoptosis values are similar. Although, there is difference between the treatments based on their \% apoptosis results. This clearly indicates that dual treatment has greater effect and shows different results when compared leptomycin B or DR5 alone treatment. Hence, addition of leptomycin B to DR5 makes a significant difference. In case of nutlin treatment, nutlin alone treatment and nutlin combined with dual treatment show different values, which 


\begin{tabular}{|c|c|c|c|c|c|c|c|}
\hline Target gene & $\mathrm{C}_{\mathrm{t}}$ value [control] & $\mathrm{C}_{\mathrm{t}}$ value [treated] & $\begin{array}{l}\Delta \mathrm{C}_{\mathrm{t}} \text { value } \\
\text { [control] }\end{array}$ & $\begin{array}{l}\Delta \mathrm{C}_{\mathrm{t}} \text { value } \\
\text { [treated] }\end{array}$ & $\Delta \Delta \mathrm{C}_{\mathrm{t}}$ value & $2^{-\Delta \Delta C t}$ value & Gene expression \\
\hline HPRT [reference] & 32.232 & 32.38 & 0 & 0 & 0 & 1 & $\underline{ }$ \\
\hline BIRC 3 & 31.123 & 30.853 & -1.109 & -1.527 & -0.418 & 1.336 & 1.3 fold increase \\
\hline BIRC 4 & 31.732 & 31.388 & -0.5 & -0.992 & -0.492 & 1.406 & 1.4 fold increase \\
\hline DR4 & 32.32 & 33.53 & 0.088 & 1.15 & 1.062 & 0.478 & $\sim 2$ fold decrease \\
\hline DR5 & 31.532 & 30.292 & -0.7 & -2.088 & -1.388 & 2.617 & 2.6 fold increase \\
\hline DCR 1 & 32.824 & 31.568 & 0.592 & -0.812 & -1.404 & 2.646 & 2.65 fold increase \\
\hline DCR 2 & 31.721 & 30.856 & -0.511 & -1.524 & -1.013 & 2.018 & 2 fold increase \\
\hline c-FLIP & 30.327 & 29.509 & -1.905 & -2.871 & -0.966 & 1.953 & $\sim 2$ fold increase \\
\hline
\end{tabular}

Table 13: Effect of $1 \mathrm{nM}$ leptomycin $B$ on the change in gene expression of a specific set of genes related to apoptosis in MCF 7 cells using $C_{t}$ values obtained by RT-PCR.

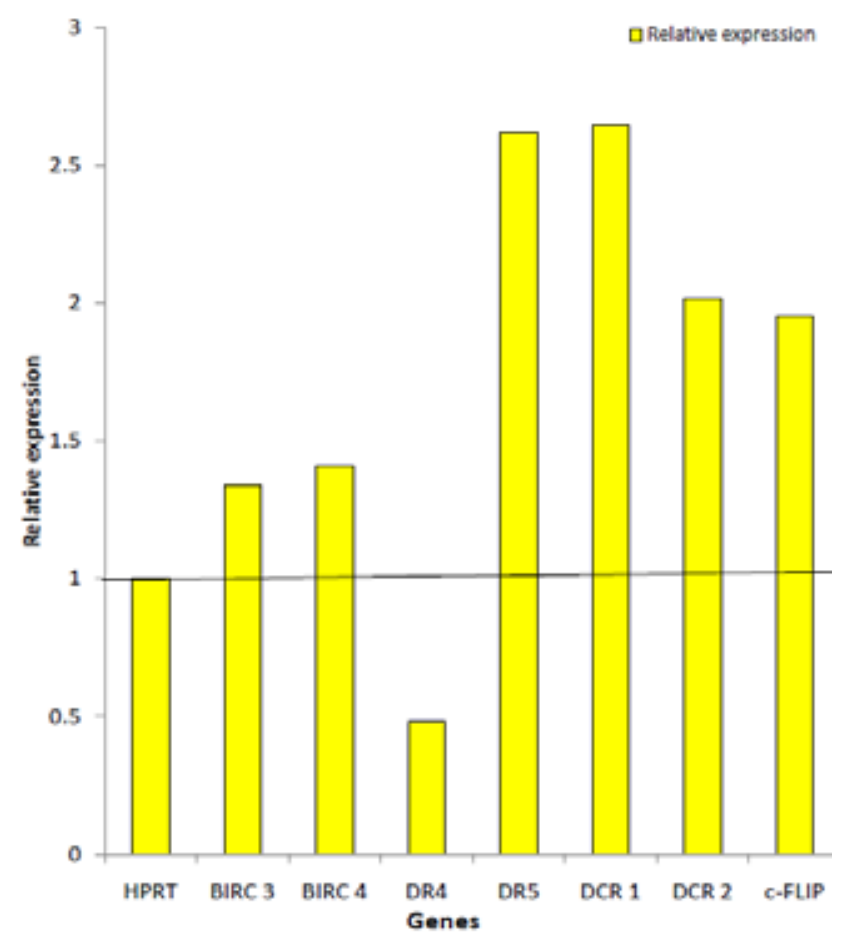

Figure 52: Graph showing the effect on $1 \mathrm{nM}$ leptomycin B on the change in gene expression of a specific set of genes related to apoptosis in MCF7 cells using $2^{-\Delta \Lambda C t}$ values.

again indicates that adding nutlin to dual treatment makes a significant difference. Whereas, based on the effect of nutlin and nutlin + dual treatment between the different cell lines, the p-values indicate that there is no significant difference. This clearly indicates that there is another mechanism through which apoptosis is induced in addition to p53 induced apoptosis.

\section{Effect of Leptomycin B on expression of genes related to p53}

On the basis on gene expression levels obtained through RT-PCR, it can be observed that: (a) the apoptotic genes DR4 has been found to be up regulated whereas DR5 has been found to be downregulated; (b) the anti apoptotic genes such as BIRC 3, BIRC 4, DCR1, DCR 2 and c-FLIP have been found to be relatively upregulated in spite of the fact that leptomycin B induces apoptosis. Based on these results, it can be summarized that the expression of these anti apoptotic genes is not sufficient to prevent apoptosis and killing of the cells by leptomycin B.
The expression of other apoptotic and anti apoptotic genes has to test to find out the hidden effects of leptomycin B.

\section{Summary}

Leptomycin B possesses great potency in killing cancer cells and its effect can be increased in combination with DR5. Nutlin has already proven to be a potent anti cancer agent, and with the set of experiments performed in this project, it can be observed that nutlin when added to leptomycin B and DR5 can boost the percentage of apoptosis even in p53 null mutants like PC3 cells. In summary, it can be stated that leptomycin B and nutlin show effects in addition to p53 independent apoptosis when added to PC3, LNCAP and MCF 7 cells. Leptomycin $\mathrm{B}$ and nutlin have shown to increase the percentage of apoptosis when added along with DR5 agonist antibody. The p53 independent activity of leptomycin B has to be studied to understand its exact molecular effects. Further research has to be carried out using dual treatment 


\begin{tabular}{|l|l|l|l|l|l|l|l|}
\hline Target gene & $\mathbf{C}_{\mathbf{t}}$ value [control] & $\begin{array}{l}\mathbf{C}_{\mathbf{t}} \text { value } \\
\text { [treated] }\end{array}$ & $\boldsymbol{\Delta} \mathbf{C}_{\mathbf{t}}$ value [control] & $\begin{array}{l}\Delta \mathbf{C}_{t} \text { value } \\
\text { [treated] }\end{array}$ & $\boldsymbol{\Delta \Lambda} \mathbf{C}_{\mathbf{t}}$ value & $\mathbf{2}^{-\Delta \Lambda C t}$ value & Gene expression \\
\hline HPRT [reference] & 32.218 & 31.652 & 0 & 0 & 0 & 1 & \\
\hline BIRC 3 & 31.564 & 29.894 & -0.654 & -1.758 & -1.104 & 2.149 & 2.14 fold increase \\
\hline BIRC 4 & 31.034 & 31.342 & -1.184 & -0.31 & 0.874 & 0.545 & 1.8 fold decrease \\
\hline DR4 & 32.178 & 33.498 & -0.04 & 1.846 & 1.886 & 0.27 & 3.7 fold decrease \\
\hline DR5 & 31.531 & 30.742 & -0.687 & -0.91 & -0.223 & 1.167 & 1.16 fold increase \\
\hline DCR 1 & 32.327 & 31.212 & 0.109 & -0.44 & -0.549 & 1.463 & 1.46 fold increase \\
\hline DCR 2 & 31.479 & 29.282 & -0.739 & -2.37 & -1.631 & 0.322 & 0.3 fold increase \\
\hline C-FLIP & 30.341 & 28.254 & -1.877 & -3.391 & -1.521 & 2.869 & 2.9 fold increase \\
\hline
\end{tabular}

Table 14: Effect of $5 \mathrm{nM}$ leptomycin B on the change in gene expression of a specific set of genes related to apoptosis in MCF 7 cells using $\mathrm{C}_{t}$ values obtained by RT-PCR.

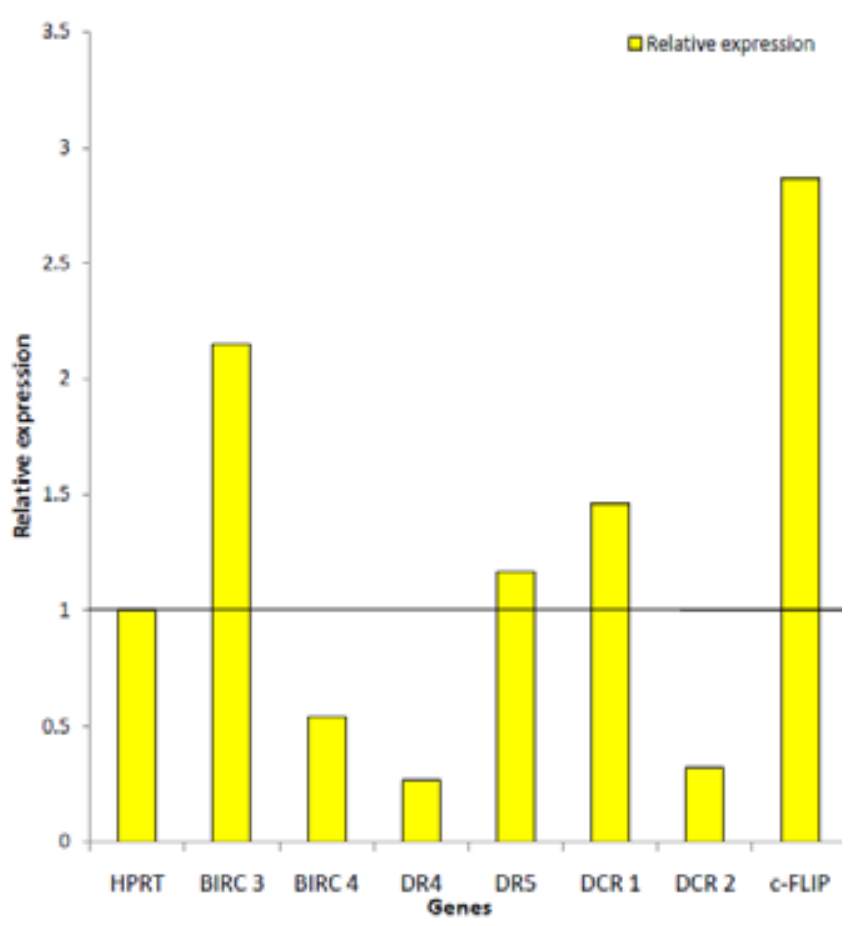

Figure 53: Graph showing effect on $5 \mathrm{nM}$ leptomycin $\mathrm{B}$ on the change in gene expression of a specific set of genes related to apoptosis in MCF7 cells using $\mathrm{C}_{t}$ values.

[leptomycin B + DR5] on cancer cells to confirm these results and further investigation has to be done to confirm the p53 independent effects of leptomycin B and nutlin 3a.

\section{References}

1. Kleinsmith LJ (2006) Principles of Cancer Biology. Pearson Benjamin Cummings.

2. Croce CM (2008) Oncogenes and cancer. N Engl J Med 358: 502-511.

3. Kinzler KW, Vogelstein B (1998) Landscaping the cancer terrain. Science 280: 1036-1037.

4. Hanahan D, Weinberg RA (2000) The hallmarks of cancer. Cell 100: 57-70.

5. Weinberg RA (1995) The retinoblastoma protein and cell cycle control. Cell 81: $323-330$

6. Giancotti FG, Ruoslahti E (1999) Integrin signaling. Science 285: 1028-1032.

7. Skobe M, Fusenig NE (1998) Tumorigenic conversion of immortal human keratinocytes through stromal cell activation. Proc Natl Acad Sci U S A 95: 1050-1055.
8. Hayflick L (1997) Mortality and immortality at the cellular level. A review. Biochemistry (Mosc) 62: 1180-1190.

9. Bryan TM, Cech TR (1999) Telomerase and the maintenance of chromosome ends. Curr Opin Cell Biol 11: 318-324.

10. Bergers G, Javaherian K, Lo KM, Folkman J, Hanahan D (1999) Effects of angiogenesis inhibitors on multistage carcinogenesis in mice. Science 284 : 808-812.

11. Volpert OV, Dameron KM, Bouck N (1997) Sequential development of an angiogenic phenotype by human fibroblasts progressing to tumorigenicity. Oncogene 14: 1495-1502.

12. Maxwell PH, Wiesener MS, Chang GW, Clifford SC, Vaux EC, et al. (1999) The tumour suppressor protein VHL targets hypoxia-inducible factors for oxygendependent proteolysis. Nature 399: 271-275.

13. Christofori G, Semb H (1999) The role of the cell-adhesion molecule E-cadherin as a tumour-suppressor gene. Trends Biochem Sci 24: 73-76.

14. Love S (2003) Apoptosis and brain ischaemia. Prog Neuropsychopharmacol Biol Psychiatry 27: 267-282.

15. Ashe PC, Berry MD (2003) Apoptotic signaling cascades. Prog Neuropsychopharmacol Biol Psychiatry 27: 199-214. 
16. Chang HY, Yang $X$ (2000) Proteases for cell suicide: functions and regulation of caspases. Microbiol Mol Biol Rev 64: 821-846.

17. Chan SL, Mattson MP (1999) Caspase and calpain substrates: roles in synaptic plasticity and cell death. J Neurosci Res 58: 167-190.

18. Wei MC, Zong WX, Cheng EH, Lindsten T, Panoutsakopoulou V, et al. (2001) Proapoptotic BAX and BAK: a requisite gateway to mitochondrial dysfunction and death. Science 292: 727-730.

19. Bratton SB, Cohen GM (2001) Apoptotic death sensor: an organelle's alter ego? Trends Pharmacol Sci 22: 306-315.

20. Zou H, Li Y, Liu X, Wang X (1999) An APAF-1.cytochrome c multimeric complex is a functional apoptosome that activates procaspase-9. J Biol Chem 274: 11549-11556.

21. Wajant $H$ (2002) The Fas signaling pathway: more than a paradigm. Science 296: 1635-1636.

22. Gross A, Yin XM, Wang K, Wei MC, Jockel J, et al. (1999) Caspase Cleaved Bid Targets Mitochondria And Is Required For Cytochrome C Release, While Bcl-XL Prevents This Release But Not Tumor Necrosis Factor R1/Fas Death. J Biol Chem 274: 1156-1163

23. Madesh M, Antonsson B, Srinivasula SM, Alnemri ES, Hajnóczky G (2002) Rapid kinetics of tBid-induced cytochrome $c$ and Smac/DIABLO release and mitochondrial depolarization. J Biol Chem 277: 5651-5659.

24. Irmler M, Thome M, Hahne M, Schneider P, Hofmann K, et al. (1997) Inhibition Of Death Receptor Signals By Cellular FLIP. Nature 388: 190- 195.

25. Jiang Y, Woronicz JD, Liu W, Goeddel DV (1999) Prevention of constitutive TNF receptor 1 signaling by silencer of death domains. Science 283: 543-546.

26. Guo Y, Srinivasula SM, Druilhe A, Fernandes-Alnemri T, Alnemri ES (2002) Caspase-2 induces apoptosis by releasing proapoptotic proteins from mitochondria. J Biol Chem 277: 13430-13437.

27. Devin A, Lin Y, Yamaoka S, Li Z, Karin M, et al. (2001) The alpha and beta subunits of IkappaB kinase (IKK) mediate TRAF2-dependent IKK recruitment to tumor necrosis factor (TNF) receptor 1 in response to TNF. Mol Cell Biol 21: 3986-3994.

28. Smyth MJ, Takeda K, Hayakawa Y, Peschon JJ, van den Brink MR, et al. (2003) Nature's TRAIL--on a path to cancer immunotherapy. Immunity 18: 1-6.

29. Janssen EM, Droin NM, Lemmens EE, Pinkoski MJ, Bensinger SJ, et al. (2005) CD4+ T-cell help controls CD8+ T-cell memory via TRAIL-mediated activationinduced cell death. Nature 434: 88-93.

30. Kimberley FC, Screaton GR (2004) Following a TRAIL: update on a ligand and its five receptors. Cell Res 14: 359-372.

31. Shi $Y$ (2004) Caspase activation, inhibition, and reactivation: a mechanistic view. Protein Sci 13: 1979-1987.

32. Golks A, Brenner D, Fritsch C, Krammer PH, Lavrik IN (2005) C-FLIPR, a new regulator of death receptor-induced apoptosis. J Biol Chem 280: 14507-14513.

33. Sprick MR, Walczak H (2004) The interplay between the Bcl-2 family and death receptor-mediated apoptosis. Biochim Biophys Acta 1644: 125-132.

34. LeBlanc HN, Ashkenazi A (2003) Apo2L/TRAIL and its death and decoy receptors. Cell Death Differ 10: 66-75.

35. Zhang XD, Borrow JM, Zhang XY, Nguyen T, Hersey P (2003) Activation of ERK1/2 protects melanoma cells from TRAIL-induced apoptosis by inhibiting Smac/DIABLO release from mitochondria. Oncogene 22: 2869-2881.

36. Chen X, Kandasamy K, Srivastava RK (2003) Differential roles of RelA (p65) and c-Rel subunits of nuclear factor kappa B in tumor necrosis factor-related apoptosis-inducing ligand signaling. Cancer Res 63: 1059-1066.

37. Falschlehner C, Emmerich CH, Gerlach B, Walczak H (2007) TRAIL signalling: decisions between life and death. Int J Biochem Cell Biol 39: 1462-1475.

38. Kaplan-Lefko PJ, Graves JD, Zoog SJ, Pan Y, Wall J, et al. (2010) Conatumumab, A Fully Human Agonist Antibody To Death Receptor 5, Induces Apoptosis Via Caspase Activation In Multiple Tumor Types. Cancer Biol Ther 9: 618-631.
39. Adams C, Totpal K, Lawrence D, Marsters S, Pitti R, et al. (2008) Structural and functional analysis of the interaction between the agonistic monoclonal antibody Apomab and the proapoptotic receptor DR5. Cell Death Differ 15: 751-761.

40. Takeda K, Yamaguchi N, Akiba H, Kojima Y, Hayakawa Y, et al. (2004) Induction of tumor-specific T cell immunity by anti-DR5 antibody therapy. J Exp Med 199: 437-448.

41. Kruyt FA (2008) TRAIL and cancer therapy. Cancer Lett 263: 14-25.

42. Baader E, Toloczko A, Fuchs U, Schmid I, Beltinger C, et al. (2005) Tumor necrosis factor-related apoptosis-inducing ligand-mediated proliferation of tumor cells with receptor-proximal apoptosis defects. Cancer Res 65: 78887895.

43. Cox ML, Meek DW (2010) Phosphorylation of serine 392 in p53 is a common and integral event during p53 induction by diverse stimuli. Cell Signal 22: 564 571.

44. Okorokov AL, Orlova EV (2009) Structural biology of the p53 tumour suppressor Curr Opin Struct Biol 19: 197-202.

45. Solozobova V, Blattner C (2010) Regulation of p53 in embryonic stem cells Exp Cell Res 316: 2434-2446.

46. Fred B (2008) Principles Of Cancer Genetics. Baltimore, USA, Springer.

47. Evan GI, Vousden KH (2001) Proliferation, cell cycle and apoptosis in cancer. Nature 411: 342-348

48. Bai L, Zhu WG (2006) P53: Structure, Function And Therapeutic Applications $\mathrm{J}$ Cancer Mol 2: 141-153.

49. Whibley C, Pharoah PD, Hollstein M (2009) p53 polymorphisms: cancer implications. Nat Rev Cancer 9: 95-107.

50. Kudo N, Wolff B, Sekimoto T, Schreiner EP, Yoneda Y, et al. (1998) Leptomycin $B$ inhibition of signal-mediated nuclear export by direct binding to CRM1. Exp Cell Res 242: 540-547.

51. Nishi K, Yoshida M, Fujiwara D, Nishikawa M, Horinouchi S, et al. (1994) Leptomycin B targets a regulatory cascade of crm1, a fission yeast nuclear protein, involved in control of higher order chromosome structure and gene expression. J Biol Chem 269: 6320-6324.

52. Mutka SC, Yang WQ, Dong SD, Ward SL, Craig DA, et al. (2009) Identification of nuclear export inhibitors with potent anticancer activity in vivo. Cancer Res 69: 510-517.

53. Shao C, Lu C, Chen L, Koty PP, Cobos E, et al. (2011) p53-Dependent anticancer effects of leptomycin $B$ on lung adenocarcinoma. Cancer Chemother Pharmacol 67: 1369-1380.

54. Vaseva AV, Marchenko ND, Moll UM (2009) The transcription-independent mitochondrial p53 program is a major contributor to nutlin-induced apoptosis in tumor cells. Cell Cycle 8: 1711-1719.

55. Chumakov PM (2007) Versatile functions of p53 protein in multicellular organisms. Biochemistry (Mosc) 72: 1399-1421.

56. Morselli E, Galluzzi L, Kepp O, Kroemer G (2009) Nutlin kills cancer cells via mitochondrial p53. Cell Cycle 8: 1647-1648. 